\title{
Validity of Weak-Form Market Efficiency in Central and Eastern European Countries (CEECs): Evidence from Linear and Nonlinear Unit Root Tests
}

\section{Mehmet Levent Erdas ${ }^{1}$}

\begin{abstract}
This paper aims to focus weekly stock market prices from the CEECs (Lithuania, Hungary, Romania, Croatia, Slovenia, Poland, Bulgaria, the Slovak Republic, Latvia, Estonia, and the Czech Republic) markets for evidence of weak-form market efficiency. This is complemented by the use of comprehensive unit root tests to test for abnormal return behaviour in these stock markets. For this purpose, Harvey et al. (2008) linearity test was applied in order to determine the characteristics of the series. The results indicate that the series with linear characteristics are Slovenia, Bulgaria, the Slovak Republic, Estonia, and the Czech Republic and those with non-linear characteristics are Lithuania, Hungary, Romania, Croatia, Poland, and Latvia. Then, in order to examine the weak-form market efficiency, DF-GLS (1996), Phillips-Perron (1988) and Lee-Strazicich (2003) unit root tests are applied to linear series and Kapetanios et al. (2003) and Kruse (2011) tests were applied to nonlinear series. The linear and nonlinear unit root tests evidence that all the selected stock markets in CEECs have a unit root, in other words, are non-stationary. In the period analyzed, the results suggest that the weak-form efficient market hypothesis holds in the CEECs. Accordingly, the results indicate support for the validity of the random walks hypothesis in all the selected stock markets in CEECs. It means that investors should not be able to earn abnormal returns by carrying out the same analysis and analysing historical prices in CEECs. The finding of weak-form market efficiency has notable implications from the point of capital allocation, stock price predictability, and the influence of shocks to stock prices.
\end{abstract}

Keywords: Central and Eastern European Countries, Linear and Nonlinear Unit Root Tests, Weak-Form Market Efficiency, Random Walk Hypothesis.

JEL Classification: G14, G15, C22

Received: 11 March 2019 / Accepted: 26 November 2019 / Sent for Publication: 5 December 2019

\footnotetext{
${ }^{1}$ Akdeniz University, Faculty of Serik Business Management, Department of Economics and Finance, Antalya, Turkey; e-mail: leventerdas@gmail.com.
}

(C) 2019 by the authors; licensee Review of Economic Perspectives / Národohospodářský obzor, Masaryk University, Faculty of Economics and Administration, Brno, Czech Republic. This article is an open access article distributed under the terms and conditions of the Creative Commons Attribution 3.0 license, Attribution - Non Commercial - No Derivatives. 


\section{Introduction}

In recent decades, the importance of the stock market's role in economic development has been realized by many governments, financial institutions, and investors. Stock markets are the most significant lead indicator of any economy especially emerging and developing markets (Nisar and Hanif, 2012: 414). The investors who are planning to invest in the capital markets try to make their decisions primarily on the factors affecting the previous price movements and transaction volumes on the equities and prices of the equities and then on price forecasting. As economies progress, more capitals and investments are needed to meet economic growth; and if the efficient market hypothesis $(\mathrm{EMH})$ is valid in the stock market, it is possible to provide an opportunity as a durable tool in the mobilization and allocation of savings among competing uses which are substantial to the growth of any countries (Manasseh et al., 2016: 1474). Hence, the issue of measuring market efficiency is important for security analysts, investors for investment decision and policymakers (Khan and Khan, 2016: 14).

The EMH is still a major issue in the finance literature and the concept of EMH is sound. EMH is substantially associated with the logic of the RWH. The equity prices; which are formed through the purchase and sale transaction and other public information; both act as a guide for the investors to make more accurate decisions on their investments, and enable a better allocation of the funds between the companies; and thus they also enable to provide a higher economic growth rate (Yartey and Adjasi, 2007: 4). Accordingly, the concept of efficient market and RWH are two crucial subjects in terms of explanation of the security price movements and behaviors of the investors within the economy and finance literature (Atakan, 2008: 99).

Current or potential investors who are considering investment in the securities exchanges calculate the expected values of the equity prices while making decisions on their investments. If the equity price is lower than the expected value, they decide to purchase it; and if it is higher than the expected value, they decide to sell it. If the market is efficient, the expected price and the current price will be the same since the price of the equities contains all information (Gemici and Polat, 2018: 139). If the EMH is valid for the relevant stock market, it is reflected in the information immediately, so it is not possible to predict the price from the previous data by the investors, so technical analysis for this phenomenon does not work for investors (Gilani et al., 2015: 28).

The idea on that the price movements are formed randomly in the markets and their distribution is incidental, and therefore they cannot be estimated in advance is first suggested by Paul Samuelson (1965) and Fama (1965) with the name "efficient market hypothesis" to the contemporary literature in finance, and outlined as the idea that prices of financial assets fully reflect all available information. Both of them stated that the EMH presumes that stock return arranges immediately for any new data (Kofarbai and Zubairu, 2016: 261). Fama (1970), who brought the concept of efficient markets in the literature, described it as a market where numerous rational profit maximization compete in actively, the future market value of each equity is tried to be estimated and all of the important current information can be obtained by all of the market participants almost cost-free (Chuvakhin, 2001: 3). The EMH seeks answers for the question of whether the information types such as historical prices, internal information and other documentation and information can be used to provide returns above average. The EMH 
depends on the speed and direction of the prices against new information. Within the efficient market, if the new information on the values of the equities arises due to the competition between the investors, the whole effect of this information will reflect on the market prices immediately (Fama, 1970). As a result of the new information, it will not be possible for the investors to provide supernormal returns when the prices of the securities applied to the new information accurately and expeditiously (Karan, 2004: 271; Nisar and Hanif, 2012: 414). The prices formed in an efficient market reflect on the information causing the formation of the historical prices. The investors make their decisions on purchasing and selling by following the historical prices (Sarikamis, 2000: 144; Atan et al., 2009: 35). Consequently, the EMH can be approached as containing two claims: (1) stock returns are random in an efficient market; (2) market participants cannot gain abnormal profit in such a market.

There are a couple of ways that help to determine whether the efficient market is efficient. One of those ways is to test the RWH (Yucel, 2016: 109). The RWH is one of the tests utilized to determine whether stock prices follow a random movement or not (Ananzeh, 2016: 173). The main aim to test the RWH is whether the information such as the historical price and transaction values, other public information and internal information can be used to provide supernormal returns (Kiyilar, 1997: 2). It is stated with the RWH that the successive price changes are independent based on the prices which reflect all of the obtainable information completely and they also have the same distribution (Ananzeh, 2014: 119; Kiyilar, 1998: 95). It is also said with the RWH that the equity prices move independently from the historical prices; in other words, the historical price movements do not affect the estimation of future prices (Narayan and Smyth, 2004: 707). Besides, if a price movement of equity has a structure with mean reversion or it follows a stationarity process; it means that the shocks on the equity prices will be temporary, the prices will return into their trends. From the viewpoints of the investors, this means that it is possible to estimate the future price movements to provide abnormal returns by following the behaviors of the equities (Gozbasi, 2014: 8).

It can be concluded that the weak-form of EMH is valid in cases where the prices are conformed with the RWH (Atakan, 2008: 99). According to the hypothesis, there is a relation between the prices of the securities and information, and they are always formed according to the new information declared. The markets are classified according to the type of new information reflected by the prices (Fama, 1970: 383). Fama (1970) classified the tests regarding the EMH based on three levels of markets: weak-form, semi-strong form and the strong form of market efficiency. Accordingly; the situation where all information related to the historical securities is reflected in the prices forms the weak efficient market, the situation where all public information is reflected in the prices of the securities forms the semi-strong efficient market, and the situation where not only public information but also in-company information are reflected in the prices of the securities forms the strong efficient market (Fama, 1991: 1576). This research focused only on the weak-form market efficiently of the selected stock markets of CEECs.

There are two assumptions to be implemented for the weak efficiency. The first of them is the non-stationarity of the series and independent and homogeneous distribution of the residuals from the random model. It is necessary by testing the weak-form of the hypothesis where the changes in the prices of the securities are completely random. The 
changes in the prices should conform to the RWH here. Therefore, testing the weakform of EMH will transform into testing RWH. It is suggested with the weak EMH that the previous returns of the current prices of the securities reflect the data such as other information on the securities and transaction value. If the weak-form of the effective market is valid for a market, the changes in the prices of the securities are formed completely random. Therefore, it will not be possible to try to estimate the future price of the securities by using their historical price series. Accordingly, it is possible to say that the utilization of the technical analysis will not provide extra earnings if the market is efficient in the weak-form (Novickyte and Degutis, 2014: 8-9). In sum; the weak efficient markets are the markets where any kind of information on the future prices cannot be provided through the historical prices; and therefore, the investors who make shortterm forward purchase and sale through buy and hold strategy cannot provide supernormal returns compared to the ordinary investors by using information such as historical prices and transaction volume.

The performance of the stock markets is considered as a very important indicator to evaluate the performance of the economy. Accordingly, equity markets and stock markets play an important role in every economy. The existence of RWH in the stock market has significant implications for issuers of equity and portfolio investors. As Worthington and Higgs (2006) indicated in their study, the existence of the EMH in the equity markets supports the direction of the direct foreign investments to the country, market inclusion and increases in the saving rates. Hence, RWH and EMH have been broadly tested financial and economic fields with diverse results from both developed and developing capital markets. Accordingly, the purpose of this study is to reveal whether the investors make investments in the real values of the equities with the decisions they made in exchanges of the countries in the CEECs by testing the validity of the weak-form of the EMH in those exchanges. The countries in the analysis are in the group of developing and underdeveloped countries. Considering the literature and theoretical studies, these countries are likely to be efficient in weak-form. In line with this expectation, the major focus of this paper is to investigate the weak-form of the EMH in the market indices of CEECs from January 2010 to December 2018. This paper contributes to the empirical literature on the validity of weak-form market efficiency for CEECs by using both new econometric techniques and comprehensive unit root analysis.

The remainder of this paper is organized as follows: The next section comprises of literature review on the validity of the weak-form efficiency. Afterward, the research methodology is presented. Then, the data and experimental results are reported and discussed. The last section includes the attempts of the paper with important issues on policy implications and future studies.

\section{Literature review}

As Conkar et al. (2018) indicated in their study; since an efficient market plays an important role in the development of the economy and also of the financial sector through the formation of the source allocation capital and distribution of the channels of the assets, researching the market efficiency is crucial for academicians, implementers and policymakers (Sakarya et al., 2018: 102). Therefore, there are a lot of researches on the validity of the EMH for different countries in the literature. In the tests for the weak- 
form of the EMH, different testing methods such as autocorrelation coefficients, stationarity tests, normal distribution analysis, run tests, and unit root tests were used. The majority of these methods are based on the unit root analysis in the literature. Therefore, these studies tested the weak-form of the efficient market hypothesis. Within the tests for the weak-form of the EMH, one can distinguish the tests for controlling the RWH. Although the statistical and econometric tests used in the researches are different, researching the validity of the weak-form of the EMH of the financial series, which is the subject of this study is also the common ground of almost all studies.

In this section, the most recognized studies on the weak-form market efficiency in the developed and developing markets are presented. The researchers are done in different countries, the results, the statistical and econometric methods are presented in Table 1 in summary.

Table 1. Selected studies on the weak-form market efficiency for stock markets

\begin{tabular}{|c|c|c|c|}
\hline Studies/Year & Stock Markets/Data & Methodologies & Results \\
\hline $\begin{array}{l}\text { Lo and } \\
\text { MacKinlay } \\
(1988)\end{array}$ & $\begin{array}{l}\text { ABD; New York and } \\
\text { AMEX Stock Exchange } \\
(1962-1985)\end{array}$ & Variance Estimators & $\begin{array}{l}\text { New York and AMEX stock } \\
\text { prices fails to exhibit RWH }\end{array}$ \\
\hline $\begin{array}{l}\text { Li and Lam } \\
\text { (1995) }\end{array}$ & $\begin{array}{l}\text { Hong Kong; Hang Seng } \\
\text { Stock (1970-1991) }\end{array}$ & $\begin{array}{l}\text { Threshold Autoregres- } \\
\text { sive Conditional Hetero- } \\
\text { scedastic }\end{array}$ & $\begin{array}{l}\text { Hang Seng stock is efficient. } \\
\text { Stock prices follow RWH }\end{array}$ \\
\hline $\begin{array}{l}\text { Al-Loughani } \\
\text { and Chap- } \\
\text { pell (1997) }\end{array}$ & $\begin{array}{l}\text { FTSE } 30 \text { Share Index } \\
(1938-1989)\end{array}$ & BDS Test & $\begin{array}{l}\text { FTSE } 30 \text { Share Index didn't hold } \\
\text { weak-form of efficiency }\end{array}$ \\
\hline $\begin{array}{l}\text { Chan et al. } \\
\text { (1997) }\end{array}$ & $\begin{array}{l}18 \text { International Markets } \\
(1961-1992)\end{array}$ & $\begin{array}{l}\text { PP Unit Root Test And } \\
\text { Cointegration Test }\end{array}$ & All the countries are efficient. \\
\hline $\begin{array}{l}\text { Choudhry } \\
\text { (1997) }\end{array}$ & $\begin{array}{l}\text { Argentina, Brazil, Co- } \\
\text { lombia, Chili México, } \\
\text { Venezuela } \\
\text { (Jan } 1989 \text { - Dec 1993) }\end{array}$ & The ADF Unit Root Test & $\begin{array}{l}\text { All countries consistent with the } \\
\text { null hypothesis of weak-form } \\
\text { efficiency. }\end{array}$ \\
\hline $\begin{array}{l}\text { Kawakatsu } \\
\text { and Morey } \\
\text { (1999) }\end{array}$ & $\begin{array}{l}\text { 16 Developing Countries } \\
\text { (Jan 1976-Dec 1997) }\end{array}$ & $\begin{array}{l}\text { DF-GLS And The KPSS } \\
\text { Unit Root Tests }\end{array}$ & $\begin{array}{l}\text { The stock markets are weak- } \\
\text { form inefficient }\end{array}$ \\
\hline $\begin{array}{l}\text { Abraham et } \\
\text { al. (2002) }\end{array}$ & $\begin{array}{l}\text { Kuwait, Bahrain, Saudi } \\
\text { Arabia } \\
\text { (Oct } 1992 \text { - Dec 1998) }\end{array}$ & The Variance Ratio & $\begin{array}{l}\text { Saudi Arabia and Bahrain are } \\
\text { efficient in weak-form, and follow } \\
\text { RWH }\end{array}$ \\
\hline $\begin{array}{l}\text { Buguk and } \\
\text { Brorsen } \\
(2003)\end{array}$ & $\begin{array}{l}\text { Borsa Istanbul (1992- } \\
\text { 1999) }\end{array}$ & $\begin{array}{l}\text { ADF Unit Root Test, } \\
\text { GPH Test Variance } \\
\text { Ratio Test }\end{array}$ & $\begin{array}{l}\text { The Borsa Istanbul is efficient in } \\
\text { the weak-form, the stock prices } \\
\text { follow RWH }\end{array}$ \\
\hline $\begin{array}{l}\text { Chaudhuri } \\
\text { and } \mathrm{Wu} \\
(2003)\end{array}$ & $\begin{array}{l}\text { Seventeen Emerging } \\
\text { Markets } \\
\text { (Jan } 1985 \text { - Apr 2002) }\end{array}$ & $\begin{array}{l}\text { Seemingly Unrelated } \\
\text { Regression Tests }\end{array}$ & $\begin{array}{l}\text { Stock prices of all these markets } \\
\text { are consistent with the weak- } \\
\text { form of EMH }\end{array}$ \\
\hline $\begin{array}{l}\text { Smith and } \\
\text { Ryoo (2003) }\end{array}$ & $\begin{array}{l}\text { Greece, Turkey, Hunga- } \\
\text { ry, Portugal and Poland } \\
\text { (Apr } 1991 \text { - Aug 1998) }\end{array}$ & $\begin{array}{l}\text { The Multivariate Ratio } \\
\text { Test }\end{array}$ & $\begin{array}{l}\text { Turkey is efficient in the weak- } \\
\text { form and exhibits price behav- } \\
\text { iour that resemble to RWH }\end{array}$ \\
\hline $\begin{array}{l}\text { Narayan } \\
\text { and Smyth } \\
(2004)\end{array}$ & $\begin{array}{l}\text { South Korea (1981- } \\
\text { 2003) }\end{array}$ & $\begin{array}{l}\text { ADF, Zivot and An- } \\
\text { drews, LP Unit Root } \\
\text { Tests }\end{array}$ & $\begin{array}{l}\text { There existed weak-form of } \\
\text { efficiency and it exhibits charac- } \\
\text { teristics of RWH }\end{array}$ \\
\hline
\end{tabular}




\begin{tabular}{|c|c|c|c|}
\hline $\begin{array}{l}\text { Worthington } \\
\text { and Higgs } \\
(2004)\end{array}$ & $\begin{array}{l}20 \text { European States } \\
\text { (Aug } 1995 \text { - May 2013) }\end{array}$ & $\begin{array}{l}\text { The Correlation Test, } \\
\text { The Run Test, The Unit } \\
\text { Root Test and The } \\
\text { Multivariate Tests }\end{array}$ & $\begin{array}{l}\text { Hungary, Germany, Ireland } \\
\text { Portugal, Sweden and the UK } \\
\text { are efficient in the weak-form }\end{array}$ \\
\hline $\begin{array}{l}\text { Narayan } \\
(2005)\end{array}$ & $\begin{array}{l}\text { Australian and New } \\
\text { Zealand } \\
\text { (Unknown Dates) }\end{array}$ & $\begin{array}{l}\text { Unit Root Tests And } \\
\text { Unrestricted Two- } \\
\text { Regime Threshold } \\
\text { Autoregressive Model }\end{array}$ & $\begin{array}{l}\text { Both countries are nonlinear } \\
\text { processes and consistent with } \\
\text { the weak-form of EMH. }\end{array}$ \\
\hline $\begin{array}{l}\text { Narayan } \\
(2006)\end{array}$ & $\begin{array}{l}\text { ABD; New York Stock } \\
\text { Exchange } \\
(1964-2003)\end{array}$ & $\begin{array}{l}\text { Unrestricted Two- } \\
\text { Regime Threshold } \\
\text { Autoregressive }\end{array}$ & $\begin{array}{l}\text { The paper that supports the } \\
\text { efficiency in weak-form for New } \\
\text { York Stock Exchange }\end{array}$ \\
\hline $\begin{array}{l}\text { Celik and } \\
\text { Tas (2007) }\end{array}$ & $\begin{array}{l}\text { Developing Countries } \\
(1998-2007)\end{array}$ & Linear Unit Root Test & $\begin{array}{l}\text { Accept weak-form efficiency and } \\
\text { RWH for many countries }\end{array}$ \\
\hline $\begin{array}{l}\text { Hasanov } \\
\text { and Omay } \\
(2007)\end{array}$ & $\begin{array}{l}\text { Bulgarian, Czech, } \\
\text { Hungarian, Slovakian } \\
\text { Stock Markets } \\
(1991-2005)\end{array}$ & $\begin{array}{l}\text { The STR Unit Root Test } \\
\text { of Kapetanios et al. } \\
\text { (2003) }\end{array}$ & $\begin{array}{l}\text { The weak-form of efficiency is } \\
\text { validity in these countries and } \\
\text { these countries follow RWH }\end{array}$ \\
\hline $\begin{array}{l}\text { Hooi and } \\
\text { Smyth } \\
(2007)\end{array}$ & $\begin{array}{l}\text { Eight Asian Countries } \\
\text { (Jan } 1998 \text { - June 2005) }\end{array}$ & $\begin{array}{l}\text { Panel Unit Root Test } \\
\text { With One or Two Struc- } \\
\text { tural Breaks }\end{array}$ & $\begin{array}{l}\text { Eight Asian countries are not } \\
\text { weak-form-efficient and these } \\
\text { markets were unable to follow } \\
\text { RWH }\end{array}$ \\
\hline $\begin{array}{l}\text { Narayan } \\
\text { and Smyth } \\
(2007)\end{array}$ & $\begin{array}{l}\text { G-7 Stock Prices } \\
(1960-2003)\end{array}$ & $\begin{array}{l}\text { Unit Root Tests With } \\
\text { One And Two Structural } \\
\text { Breaks }\end{array}$ & $\begin{array}{l}\text { Stock prices of all these markets } \\
\text { are consistent the RWH }\end{array}$ \\
\hline $\begin{array}{l}\text { Narayan } \\
\text { and Prasad } \\
(2007)\end{array}$ & $\begin{array}{l}\text { The Stock Exchange } \\
\text { Markets of } 17 \text { Countries } \\
\text { (Jan } 1988 \text { - Mar 2003) }\end{array}$ & $\begin{array}{l}\text { LLC, The SURADF And } \\
\text { The MADF Tests }\end{array}$ & $\begin{array}{l}\text { The paper that supports there } \\
\text { existed weak-form of efficiency } \\
\text { for all countries }\end{array}$ \\
\hline $\begin{array}{l}\text { Lean and } \\
\text { Smyth } \\
(2007)\end{array}$ & $\begin{array}{l}8 \text { Asian Countries } \\
\text { (Jan } 1988 \text { - June 2005) }\end{array}$ & $\begin{array}{l}\text { Two Break LM Panel } \\
\text { Unit Root Test }\end{array}$ & $\begin{array}{l}\text { The paper supported the effi- } \\
\text { ciency on these Asian countries }\end{array}$ \\
\hline $\begin{array}{l}\text { Mollah } \\
(2007)\end{array}$ & $\begin{array}{l}\text { Botswana Stock Ex- } \\
\text { change } \\
(1989-2005)\end{array}$ & $\begin{array}{l}\text { K-S Normality, Auto- } \\
\text { Correlation And Run } \\
\text { Tests Auto Regressive } \\
\text { ARIMA Model }\end{array}$ & $\begin{array}{l}\text { Botswana Stock Exchange is not } \\
\text { informationally efficient and did } \\
\text { not follow weak-form of efficien- } \\
\text { cy }\end{array}$ \\
\hline $\begin{array}{l}\text { Ozdemir } \\
\text { (2008) }\end{array}$ & $\begin{array}{l}\text { Borsa Istanbul } \\
(1990-2005)\end{array}$ & $\begin{array}{l}\text { ADF And LP Unit Root } \\
\text { Tests, Runs Test, Vari- } \\
\text { ance Ratio Test }\end{array}$ & $\begin{array}{l}\text { The paper that supports the } \\
\text { efficiency in weak-form for Borsa } \\
\text { Istanbul }\end{array}$ \\
\hline $\begin{array}{l}\text { Narayan } \\
\text { (2008) }\end{array}$ & $\begin{array}{l}\text { The Stock Markets of } \\
\text { the } \\
\text { G-7 Countries } \\
\text { (Jan } 1975-\text { Apr 2003) }\end{array}$ & $\begin{array}{l}\text { Two Break Panel LM } \\
\text { Unit } \\
\text { Root Test }\end{array}$ & $\begin{array}{l}\text { The paper that supports the } \\
\text { efficiency in weak-form for } \\
\text { Australia and New Zeeland }\end{array}$ \\
\hline $\begin{array}{l}\text { Pele and } \\
\text { Voineagu } \\
(2008)\end{array}$ & $\begin{array}{l}\text { Romanian Capital } \\
\text { Market } \\
(9 / 19 / 1997-1 / 09 / 2007) \\
\end{array}$ & $\begin{array}{l}\text { Unit Root Test, The } \\
\text { Partial Autocorrelation }\end{array}$ & $\begin{array}{l}\text { Weak-form and RWH are valid } \\
\text { for Romanian Capital Market }\end{array}$ \\
\hline $\begin{array}{l}\text { Munir and } \\
\text { Mansur } \\
(2009)\end{array}$ & $\begin{array}{l}\text { Kuala Lumpur Stock } \\
\text { Exchange Composite } \\
\text { Index (1980-2008) }\end{array}$ & $\begin{array}{l}\text { Unrestricted Two- } \\
\text { Regime Threshold } \\
\text { Autoregressive }\end{array}$ & $\begin{array}{l}\text { The stock markets are weak- } \\
\text { form efficient and they found to } \\
\text { be moving randomly }\end{array}$ \\
\hline $\begin{array}{l}\text { Gourishan- } \\
\text { kar et al. } \\
(2009)\end{array}$ & $\begin{array}{l}\text { Bombay and National } \\
\text { Stock } \\
\text { Exchanges (1997-2009) }\end{array}$ & $\begin{array}{l}\text { Non-Parametric test, } \\
\text { Runs test and BDS Test }\end{array}$ & $\begin{array}{l}\text { The stock markets are weak- } \\
\text { form efficient and it found to be } \\
\text { moving randomly }\end{array}$ \\
\hline
\end{tabular}




\begin{tabular}{|c|c|c|c|}
\hline Liu (2010) & $\begin{array}{l}\text { China Stock Market } \\
(2001-2008)\end{array}$ & $\begin{array}{l}\text { Parametric and Non- } \\
\text { Parametric Tests }\end{array}$ & $\begin{array}{l}\text { China Stock Market was unable } \\
\text { to follow weak-form of efficiency } \\
\text { and RWH }\end{array}$ \\
\hline $\begin{array}{l}\text { Irfan et al. } \\
(2010)\end{array}$ & $\begin{array}{l}\text { Karachi Stock Exchange } \\
\text { (Jan } 1999 \text { - Aug 2009) }\end{array}$ & $\begin{array}{l}\text { Unit Root Test, Autocor- } \\
\text { relation Tests and } \\
\text { ARIMA Mode }\end{array}$ & $\begin{array}{l}\text { The market is not efficient in } \\
\text { weak-form }\end{array}$ \\
\hline $\begin{array}{l}\text { Zaubia and } \\
\text { Nahlehb } \\
(2010)\end{array}$ & $\begin{array}{l}\text { Mena Countries; } \\
\text { Morocco, Tunisia, Egypt } \\
\text { Jordan Turkey (Jan } \\
2004 \text { - Dec 2006) }\end{array}$ & $\begin{array}{l}\text { ADF and PP Unit Root } \\
\text { Tests }\end{array}$ & $\begin{array}{l}\text { Stock prices of all these coun- } \\
\text { tries are consistent with the } \\
\text { weak-form and RWH }\end{array}$ \\
\hline $\begin{array}{l}\text { Borges } \\
(2010)\end{array}$ & $\begin{array}{l}\text { UK, France, Germany } \\
\text { Greece Portugal and } \\
\text { Spain } \\
\text { (Jan } 1993 \text { - Dec 2007) }\end{array}$ & $\begin{array}{l}\text { Correlation Test, The } \\
\text { Run Test, The ADF Test } \\
\text { and The Lomackinley } \\
\text { Multivariate Ratio Test }\end{array}$ & $\begin{array}{l}\text { Germany and Spain are efficient } \\
\text { in weak-form, and follow RWH }\end{array}$ \\
\hline $\begin{array}{l}\text { Lee et al. } \\
\text { (2010) }\end{array}$ & $\begin{array}{l}2 \text { Developed and } 26 \\
\text { Developing Countries } \\
\text { (Jan 1999 - May 2007) }\end{array}$ & $\begin{array}{l}\text { Multiple Structural } \\
\text { Breaks }\end{array}$ & $\begin{array}{l}\text { The paper reject the } \\
\text { null hypothesis of weak-form } \\
\text { efficiency, these economies did } \\
\text { not follow RWH }\end{array}$ \\
\hline $\begin{array}{l}\text { Alexeev and } \\
\text { Tapon } \\
\text { (2011) } \\
\end{array}$ & $\begin{array}{l}\text { Toronto Stock Exchange } \\
\text { (Aug } 1980 \text { - Aug 2010) }\end{array}$ & $\begin{array}{l}\text { ARMA, EGARCH and } \\
\text { Bootstrap Methodology }\end{array}$ & $\begin{array}{l}\text { Weak-form of efficiency and } \\
\text { RWH are valid for Toronto Stock } \\
\text { Exchange }\end{array}$ \\
\hline $\begin{array}{l}\text { Mishra } \\
(2011)\end{array}$ & $\begin{array}{l}\text { Emerging and Devel- } \\
\text { oped World Capital } \\
\text { Markets } \\
\text { (Jan } 2007 \text { - Dec 2010) }\end{array}$ & $\begin{array}{l}\text { Unit Root Test and } \\
\text { GARCH }\end{array}$ & $\begin{array}{l}\text { These economies didn't hold } \\
\text { weak-form of efficiency and were } \\
\text { not following the RWH }\end{array}$ \\
\hline $\begin{array}{l}\text { Haque et al. } \\
\text { (2011) }\end{array}$ & $\begin{array}{l}\text { Pakistani Stock Market } \\
(2000-2010)\end{array}$ & $\begin{array}{l}\text { Traditional Unit Root } \\
\text { Tests, Ljung-Box, Q- } \\
\text { Statistic of Autocorrela- } \\
\text { tions, Runs Test }\end{array}$ & $\begin{array}{l}\text { The paper rejected the RWH } \\
\text { and weak-form of efficiency }\end{array}$ \\
\hline $\begin{array}{l}\text { Kim et al. } \\
(2011)\end{array}$ & $\begin{array}{l}\text { Dow Jones Industrial } \\
\text { Average Index (Jan } \\
1900 \text { - June 2009) }\end{array}$ & $\begin{array}{l}\text { Automatic Variance } \\
\text { Ratio, Automatic Port- } \\
\text { manteau, Generalized } \\
\text { Spectral Tests }\end{array}$ & $\begin{array}{l}\text { They accept the existence of } \\
\text { weak-form of efficiency }\end{array}$ \\
\hline $\begin{array}{l}\text { Bashir et al. } \\
\text { (2011) }\end{array}$ & $\begin{array}{l}\text { Pakistani Stock Ex- } \\
\text { change } \\
\text { (June } 1997 \text { - Apr 2009) } \\
\end{array}$ & $\begin{array}{l}\text { ADF And PP Unit Root } \\
\text { Tests, Johansen Co- } \\
\text { Integration, VAR } \\
\end{array}$ & $\begin{array}{l}\text { The paper refuted the null hy- } \\
\text { pothesis of weak-form EMH }\end{array}$ \\
\hline $\begin{array}{l}\text { Mehmood et } \\
\text { al. (2012) }\end{array}$ & $\begin{array}{l}\text { Karachi Stock Exchange } \\
\text { (Jan } 2001 \text { - Nov 2011) }\end{array}$ & $\begin{array}{l}\text { ADF And PP Unit Root } \\
\text { Tests And Johansen Co- } \\
\text { Integration }\end{array}$ & $\begin{array}{l}\text { The paper accepts existence of } \\
\text { weak-form of efficiency and } \\
\text { RWH for the Karachi Stock } \\
\text { Exchange }\end{array}$ \\
\hline $\begin{array}{l}\text { Ezepue and } \\
\text { Omar } \\
(2012)\end{array}$ & $\begin{array}{l}\text { Nigerian Stock Market } \\
(2000-2010)\end{array}$ & $\begin{array}{l}\text { Parametric and Non- } \\
\text { Parametric Tests }\end{array}$ & $\begin{array}{l}\text { Not weak-form efficient and Do } \\
\text { not follow the RWH }\end{array}$ \\
\hline $\begin{array}{l}\text { Zeren and } \\
\text { Konuk } \\
(2013)\end{array}$ & $\begin{array}{l}\text { Developing Coutries; } \\
\text { Argentina, Brazil, China, } \\
\text { Indonesia, India, Philip- } \\
\text { pines Mexico, Malaysia, } \\
\text { Turkey and Russia } \\
(1988-2012)\end{array}$ & $\begin{array}{l}\text { ADF and KSS Unit Root } \\
\text { Tests }\end{array}$ & $\begin{array}{l}\text { Accept weak-form for India, } \\
\text { Argentina Indonesia, Mexico, } \\
\text { Russia and Turkey; Reject for } \\
\text { Brazil China, Philippines and } \\
\text { Malaysia }\end{array}$ \\
\hline Gozbası et & Borsa Istanbul & Nonlinear Unit Root & Borsa Istanbul is efficient in the \\
\hline
\end{tabular}




\begin{tabular}{|c|c|c|c|}
\hline al. (2014) & $\begin{array}{l}\text { (1 July } 2002 \text { - } 7 \text { July } \\
\text { 2012) }\end{array}$ & Tests & $\begin{array}{l}\text { weak-form and the stock prices } \\
\text { follow RWH }\end{array}$ \\
\hline $\begin{array}{l}\text { Gumus and } \\
\text { Zeren } \\
(2014)\end{array}$ & $\begin{array}{l}\text { G -20 Countries } \\
\text { (Various Start Dates) }\end{array}$ & $\begin{array}{l}\text { Harvey Linearity, The } \\
\text { Fourier ADF and The } \\
\text { Fourier KSS Unit Root } \\
\text { Tests }\end{array}$ & $\begin{array}{l}\text { Weak-form and RWH for the } \\
\text { markets of the nine countries }\end{array}$ \\
\hline $\begin{array}{l}\text { Gozbası } \\
(2014)\end{array}$ & $\begin{array}{l}\text { Borsa Istanbul } \\
\text { (Jan } 2004 \text { - Mar 2014) }\end{array}$ & $\begin{array}{l}\text { Harvey Linearity } \\
\text { Kapetonois et al. (2003), } \\
\text { Kruse (2011) Tests }\end{array}$ & $\begin{array}{l}\text { Borsa Istanbul is efficient in the } \\
\text { weak-form and the stock prices } \\
\text { follow RWH }\end{array}$ \\
\hline $\begin{array}{l}\text { Lee et al. } \\
\text { (2014) }\end{array}$ & $\begin{array}{l}\text { OECD, G-6, Asian and } \\
\text { Other European Econ- } \\
\text { omies } \\
\text { (Unknown Dates) }\end{array}$ & $\begin{array}{l}\text { Smooth Transition } \\
\text { Regression, Heteroge- } \\
\text { neous Panel Unit Root } \\
\text { Tests }\end{array}$ & $\begin{array}{l}\text { Accept RWH for majority of the } \\
\text { countries }\end{array}$ \\
\hline $\begin{array}{l}\text { Dragotă and } \\
\text { Țilică (2014) }\end{array}$ & $\begin{array}{l}\text { Post-Communist East } \\
\text { European Countries } \\
\text { (Jan 2008 - Dec 2010) }\end{array}$ & $\begin{array}{l}\text { Unit Root Tests, Runs } \\
\text { Test, Variance Ratio } \\
\text { Test, Filter Rules Test } \\
\text { and The January Effect }\end{array}$ & $\begin{array}{l}\text { The weak-form and RWH cannot } \\
\text { be rejected for some assets }\end{array}$ \\
\hline $\begin{array}{l}\text { Ryaly et al. } \\
(2014)\end{array}$ & $\begin{array}{l}\text { Asian Stock Markets; } \\
\text { India, South Korea, } \\
\text { Singapore, Japan, Hong } \\
\text { Kong } \\
\text { (July } 1997 \text { - Nov 2013) }\end{array}$ & $\begin{array}{l}\text { Unit Root Test, Serial } \\
\text { Correlation Test, The } \\
\text { Runs Test }\end{array}$ & $\begin{array}{l}\text { Weak-form of EMH and RWH } \\
\text { are valid for all the Asian stock } \\
\text { markets }\end{array}$ \\
\hline $\begin{array}{l}\text { Alom and } \\
\text { Raquib } \\
(2014)\end{array}$ & $\begin{array}{l}\text { Dhaka Stock Exchange } \\
(1998-2012)\end{array}$ & $\begin{array}{l}\text { Autocorrelation Function } \\
\text { Tests }\end{array}$ & $\begin{array}{l}\text { The stock market didn't hold } \\
\text { weak-form of efficiency and was } \\
\text { not following the RWH }\end{array}$ \\
\hline $\begin{array}{l}\text { Ananzeh } \\
(2014)\end{array}$ & $\begin{array}{l}\text { Amman Stock Market } \\
\text { (Jan } 2000 \text { - Dec 2013) }\end{array}$ & $\begin{array}{l}\text { ADF And PP Unit Root } \\
\text { Tests, Runs and Auto- } \\
\text { correlation Tests }\end{array}$ & $\begin{array}{l}\text { Amman Stock Market } \\
\text { stock market is inefficient at the } \\
\text { weak-form }\end{array}$ \\
\hline $\begin{array}{l}\text { Hepsag and } \\
\text { Akcalı } \\
(2015)\end{array}$ & $\begin{array}{l}\text { G-7 And E-7 Countries } \\
\text { (Various Start Dates) }\end{array}$ & $\begin{array}{l}\text { Asymmetric Nonlinear } \\
\text { Unit Root Test }\end{array}$ & $\begin{array}{l}\text { Weak-form and RWH are valid } \\
\text { for France, Italy, Japan, the } \\
\text { USA, Brazil, China, India, Indo- } \\
\text { nesia, Mexico and Turkey, } \\
\text { Canada, Germany, the UK, } \\
\text { Russia }\end{array}$ \\
\hline $\begin{array}{l}\text { Gilani et al. } \\
(2015)\end{array}$ & $\begin{array}{l}\text { Islamabad Stock Ex- } \\
\text { change } \\
\text { (Jan } 2013 \text { - Dec 2013) }\end{array}$ & Run Test and ADF Test & $\begin{array}{l}\text { The stock market is weak-form } \\
\text { inefficient and it found to be } \\
\text { moving non-randomly. }\end{array}$ \\
\hline Phiri (2015) & $\begin{array}{l}\text { Five Generalized Stock } \\
\text { Indices in the Johan- } \\
\text { nesburg Stock Ex- } \\
\text { change (Jan } 2000 \text { - Dec } \\
\text { 2014) }\end{array}$ & $\begin{array}{l}\text { Linear And Nonlinear } \\
\text { Unit Root Tests }\end{array}$ & $\begin{array}{l}\text { The linear model suggests that } \\
\text { JSE is efficient in the weak-form; } \\
\text { the nonlinear model suggests } \\
\text { that majority of the stock indices } \\
\text { didn't hold weak-form of efficien- } \\
\text { cy. }\end{array}$ \\
\hline $\begin{array}{l}\text { Said and } \\
\text { Harper } \\
(2015)\end{array}$ & $\begin{array}{l}\text { Russian Stock Market } \\
(2003-2012)\end{array}$ & $\begin{array}{l}\text { Autocorrelation and Box- } \\
\text { Ljung Test }\end{array}$ & $\begin{array}{l}\text { The market is not efficient in } \\
\text { weak-form }\end{array}$ \\
\hline $\begin{array}{l}\text { Malhotra et } \\
\text { al. (2015) }\end{array}$ & $\begin{array}{l}10 \text { Selected Stock } \\
\text { Exchanges in Asia- } \\
\text { Pacific Market } \\
(1997-2012)\end{array}$ & $\begin{array}{l}\text { Autocorrelation and Run } \\
\text { Test }\end{array}$ & $\begin{array}{l}\text { There existed weak-form of } \\
\text { efficiency for monthly returns but } \\
\text { fail to exhibit RWH in daily and } \\
\text { weekly returns }\end{array}$ \\
\hline
\end{tabular}




\begin{tabular}{|c|c|c|c|}
\hline $\begin{array}{l}\text { Nwachukwu } \\
\text { and Shitta } \\
(2015)\end{array}$ & $\begin{array}{l}24 \text { Emerging and Nine } \\
\text { Industrial Stock Market } \\
\text { Exchanges } \\
\text { (Jan } 2000 \text { - Dec 2010) }\end{array}$ & $\begin{array}{l}\text { Parametric and Non- } \\
\text { Parametric Techniques } \\
\text { and January Effects }\end{array}$ & $\begin{array}{l}\text { Stock market exchanges are } \\
\text { efficient in the weak-form, the } \\
\text { stock prices follow RWH }\end{array}$ \\
\hline $\begin{array}{l}\text { Yang et al. } \\
(2015)\end{array}$ & $\begin{array}{l}\text { MIST Stock Markets; } \\
\text { Mexico, India, South } \\
\text { Korea Turkey } \\
\text { (Apr } 2004 \text { - Apr 2012) }\end{array}$ & $\begin{array}{l}\text { Sequential Panel Selec- } \\
\text { tion Method, Fourier } \\
\text { KSS, Fourier Panel KSS }\end{array}$ & $\begin{array}{l}\text { Stock markets of all these mar- } \\
\text { kets are consistent with the } \\
\text { weak-form of efficient market }\end{array}$ \\
\hline $\begin{array}{l}\text { Hussain et } \\
\text { al. (2016) }\end{array}$ & $\begin{array}{l}\text { Chittagong Stock Ex- } \\
\text { change } \\
(2006-2016)\end{array}$ & $\begin{array}{l}\text { Run Test Autocorrela- } \\
\text { tion Test Coefficient } \\
\text { Test, Ljung-Box Statis- } \\
\text { tics }\end{array}$ & $\begin{array}{l}\text { The paper refuted the null hy- } \\
\text { pothesis of weak-form efficiency. }\end{array}$ \\
\hline $\begin{array}{l}\text { Anlas and } \\
\text { Toraman } \\
(2016)\end{array}$ & $\begin{array}{l}\text { Turkish Stock Market } \\
(1988-2011)\end{array}$ & $\begin{array}{l}\text { Multiple Structural } \\
\text { Breaks }\end{array}$ & $\begin{array}{l}\text { Turkish Stock Market } \\
\text { follows RWH }\end{array}$ \\
\hline $\begin{array}{l}\text { Khan and } \\
\text { Khan (2016) }\end{array}$ & $\begin{array}{l}\text { Karachi Stock Exchange } \\
(1991-2015)\end{array}$ & $\begin{array}{l}\text { Unit Root Tests, The } \\
\text { Run Test and Autocorre- } \\
\text { lation Test }\end{array}$ & $\begin{array}{l}\text { Unit root tests reveal that the } \\
\text { KSE is efficient in the weak- } \\
\text { form, the run and autocorrelation } \\
\text { tests reveal that there is no } \\
\text { validity of weak-form efficiency } \\
\text { of KSE }\end{array}$ \\
\hline $\begin{array}{l}\text { Malcioglu } \\
\text { and Aydin } \\
(2016)\end{array}$ & $\begin{array}{l}\text { Istanbul Stock Exchange } \\
(3.7 .2000-22.9 .2015)\end{array}$ & Harvey Linearity Test & $\begin{array}{l}\text { There is no existence of weak- } \\
\text { form efficiency of ISE }\end{array}$ \\
\hline $\begin{array}{l}\text { Rahman et } \\
\text { al. (2016) }\end{array}$ & $\begin{array}{l}\text { Chittagong Stock Ex- } \\
\text { change } \\
(2006-2015)\end{array}$ & $\begin{array}{l}\text { Parametric/Non- } \\
\text { Parametric Methods }\end{array}$ & $\begin{array}{l}\text { There is no existence of weak- } \\
\text { form efficiency of Chittagong } \\
\text { Stock Exchange }\end{array}$ \\
\hline $\begin{array}{l}\text { Yucel } \\
\text { (2016) }\end{array}$ & $\begin{array}{l}\text { Borsa Istanbul } \\
(2000-2015)\end{array}$ & Unit Root Tests & $\begin{array}{l}\text { All indexes in Borsa Istanbul } \\
\text { follow the weak-form of EMH } \\
\text { and consistent with the RWH }\end{array}$ \\
\hline $\begin{array}{l}\text { Pervez et al. } \\
\text { (2018) }\end{array}$ & $\begin{array}{l}\text { Dhaka Stock Exchange } \\
\text { (June } 2004 \text { - Mar 2018) }\end{array}$ & $\begin{array}{l}\text { K-S Test with Lilliefors } \\
\text { Coefficient, Run Test, } \\
\text { Autocorrelation Test, } \\
\text { Unit Root Tests and } \\
\text { Variance Ratio Test }\end{array}$ & $\begin{array}{l}\text { Dhaka Stock Exchange is weak- } \\
\text { form inefficient and it found to be } \\
\text { moving non-randomly }\end{array}$ \\
\hline $\begin{array}{l}\text { Tokić et al. } \\
(2018)\end{array}$ & $\begin{array}{l}\text { Developing Eastern } \\
\text { European Countries; } \\
\text { Croatia, Serbia, Slove- } \\
\text { nia, Slovakia } \\
\text { (Jan } 2006 \text { - Dec 2016) } \\
\end{array}$ & $\begin{array}{l}\text { Serial Correlation Test, } \\
\text { Runs Test, Unit Root } \\
\text { Tests, Variance Ratio } \\
\text { Test and January Effect }\end{array}$ & $\begin{array}{l}\text { Croatia, Slovenia, Slovakia } \\
\text { confirm the validity of weak-form } \\
\text { of EMH }\end{array}$ \\
\hline $\begin{array}{l}\text { Gemici and } \\
\text { Polat (2018) }\end{array}$ & $\begin{array}{l}\text { MIST Countries; } \\
\text { Mexico, Indonesia, } \\
\text { South Korea Turkey } \\
\text { (Jan } 1988 \text { - July 2017) }\end{array}$ & Furuoka Unit Root Test & $\begin{array}{l}\text { These markets are not efficient } \\
\text { in weak-form }\end{array}$ \\
\hline
\end{tabular}

Source: Author's compilation.

In literature, EMH is examined by parametric and non-parametric tests such as variance ratio test, run test, autocorrelation test, linear, and nonlinear unit root test. The abovementioned results suggest that the weak-form of EMH and RWH are confirmed by many studies in the literature; however, they are not supported by a few studies. In light 
of the above-mentioned literature, it is evident that the mixed results are reached by various studies. In other words, the research background cannot reveal a common idea for the weak-form of efficiency in developed and developing countries. While the consensus says that stock prices in developed markets exhibit an RWH, there are no obvious outcomes regarding stock prices in developing markets. To this end, both traditional and modern econometric techniques are employed for measuring the weak-form of efficiency for developing countries in this study.

\section{Methodology}

One of the common methods preferred to research the validity of the weak-form of the EMH is unit root tests. The unit root tests are the tests performed to research the stationarity of the time-series (Tar1, 2014: 382). Using the unit root tests suitable for the structure of the equity market series will be important in terms of the reliability of the results.

It is important to research whether the series are linear before researching whether the exchange series of the relevant countries are stationarity for the accurate interpretation of the results. When the studies are reviewed, it can be observed that lots of linearity tests were developed in lots of literature. Harvey and Leybourne (2007) and Harvey et al. (2008) are frequently used in the literature. In this study, the test method developed by Harvey et al. (2008) was used to test the linearity of the series, since; this test has a better performance in terms of statistical power and size properties than the one introduced by Harvey and Leybourne (2007).

In their study, Harvey et al. (2008) suggested the following test statistics which can be calculated by using the following two test statistics which enable us to test the linearity when the stationarity features of the time-series are unknown. In the approach suggested by Harvey et al. (2008), the following weighted statistics were developed to test the stationarity under the null hypothesis and nonstationary under the alternative hypothesis (Gozbas1, 2014). Harvey et al. (2008) test statistic is calculated with the following equations. First of all, Harvey et al. (2008) suggest a weighted average of $W_{0}$ and $W_{l}$ statistics:

$W_{\lambda}=\{1-\lambda\} W_{0}+\lambda W_{1}$

where, $\lambda$ is a function that converges in probability to zero when $y_{t}$ is $\mathrm{I}(0)$ and to one when $y_{t}$ is $\mathrm{I}(1) . W_{\lambda}$ is asymptotically distributed as $\chi_{2}{ }^{2}$. While $W_{0}$, which involves null and alternative hypotheses respectively for linearity and non-linearity if the series is considered as $\mathrm{I}(0)$, is a standard Wald test; $W_{l}$, which involves null and null hypotheses respectively for linearity and non-linearity if the series is considered as I(1) is also a standard Wald test (Vasconcelos and Junior, 2016: 117). The $\lambda$ parameter in the formula indicated the weight and calculated with the following formula (Harvey et al. 2008; Harvey and Leybourne, 2007):

$\lambda(U, S)=\exp \left(-g\left(\frac{U}{S}\right)^{2}\right)$

where, $g$ represents a finite positive constant, Harvey et al. (2008) stated in their study that the value should be calculated as $U, S$. $U$ is the statistical standard unit root test of Dickey-Fuller and $S$ is the statistic of the stationarity non-parametric test of Harris et al. (2003). If the series does not contain a unit root, (U/S) $)^{2}$ diverges, resulting in $\lambda$ gets 
closer to zero, and if the series contains a unit root, (U/S $)^{2}$ converges to zero resulting in $\lambda$ gets closer to 1 (Harvey et al., 2008). The statistics of the Harvey test and $W_{0}$ statistics which test the basic hypothesis where the series is stationarity are calculated with the addition of the restricted and unrestricted residual sum of squares of the following model. To compute the statistic $W_{l}$ initially in equation (1), the coefficients are selected as they will stabilize $v_{t}$ based on the nonlinear first degree $\operatorname{AR}(1)$ model for the stationarity time-series $y_{t}$.

$y_{t}=\mu+v_{t}$

$\Delta v_{t}=\theta_{\Delta} v_{t-1}+\delta f\left(\Delta v_{t-1}, \varphi\right) \Delta v_{t-1}+\varepsilon_{t}$

where, $\theta, \delta$ and the function $f(., \varphi)$ are chosen such that $v_{t}$ is assumed to be globally stationary. In order to get the $W_{0}$ test statistics in the equation (1), the edited version of the nonlinear first degree autoregressive model with the Taylor expansion under $\varphi=0$ assumption in the stationarity time-series is presented in the following equation (4) again through the equation (3).

$\Delta v_{t}=\gamma_{1} \Delta v_{t-1}+\gamma_{2}\left(\Delta v_{t-1}\right)^{2}+\gamma_{3}\left(\Delta v_{t-1}\right)^{3}+\varepsilon_{t}$

Considering the equation (4), it is possible to present the null hypothesis for linearity and the alternative hypothesis for non-linearity respectively as follows:

$\mathrm{H}_{0,0}: \gamma_{2}=\gamma_{3}=0$

$\mathrm{H}_{1,0}: \gamma_{2} \neq 0$, or/and $\gamma_{3} \neq 0$

In order to test the hypothesis, it is possible to write the data creation process presented in equation (5) in observed $y_{t}$ as follows:

$y_{t}=\beta_{0}+\beta_{1} y_{t-1}+\beta_{2} y_{t-2}^{2}+\beta_{3} y_{t-3}^{3}+\sum_{j=1}^{p} \beta_{4} \Delta y_{t-j}+\varepsilon_{t}$

$\Delta y_{t}=\lambda_{1} \Delta y_{t-1}+\lambda_{2}\left(\Delta y_{t-1}\right)^{2}+\lambda_{3}\left(\Delta y_{t-1}\right)^{3}+\sum_{j=1}^{p} \lambda_{4}, j \Delta y_{t-j}+\varepsilon_{t}$

Where $\Delta$ and $p$ represent the difference operator and the number of delays, respectively. In the model, linearity null hypothesis $\left(\mathrm{H}_{0,0}: \beta_{2}=\beta_{3}=0\right)$ is tested against the nonlinearity alternative hypothesis by a Wald statistic $\left(\mathrm{H}_{1,0}: \beta_{2} \neq 0\right.$ and/or $\left.\beta_{3} \neq 0\right)$. Here, the statistic of the standard Wald test is:

$W_{0}=T\left(\frac{R S S_{0}^{r}}{R S S_{0}^{u}}-1\right)$

The $R S S_{0}{ }^{r}$ value within the formula indicates the total residual sum of squares of the regression model obtained by applying the restriction under the basic hypothesis, and $R S S_{0}{ }^{u}$ indicates the sum of the squared residuals in OLS and it is obtained from the RSS unrestricted model. $T$ is the number of observations. The $W_{0}$ test statistics conform with the chi-squared distribution $\chi^{2}$. In accordance with the $W_{l}$ statistics, which is compatible with the linearity test if the examined series are considered as I(1), $y_{t}$, which is the first difference of the series, are nonlinear. Thus, we assume the following nonlinear process $\operatorname{AR}(1)$ for a series $I(1)$ :

$y_{t}=\mu+v_{t}$

$\Delta v_{t}=\delta_{1} \Delta v_{t-1}+\delta_{2} f\left(\Delta v_{t-1}, \varphi\right) \Delta v_{t-1}+\varepsilon_{t}$ 
It is necessary to rewrite this data creation process through the Taylor expansion second time with the equation (7) in order to test the basic hypothesis $\left(\delta_{2}=\delta_{3}=0\right)$ on linearity.

$\Delta v_{t}=\gamma_{1} \Delta v_{t-1}+\gamma_{2}\left(\Delta v_{t-1}\right)^{2}+\gamma_{3}\left(\Delta v_{t-1}\right)^{3}+\varepsilon_{t}$

The null hypothesis of linearity and the alternative of nonlinearity are expressed respectively as:

$\mathrm{H}_{0,0}: \gamma_{2}=\gamma_{3}=0$

$\mathrm{H}_{1,0}: \gamma_{2} \neq 0$, or/and $\gamma_{3} \neq 0$

Like the previous case of analysis $\mathrm{I}(0)$, equation (8) can be rewritten as:

$y_{t}=\varsigma_{0}+\zeta_{1} y_{t-1}+\zeta_{2} y_{t-2}^{2}+\zeta_{3} y_{t-3}^{3}+\sum_{j=1}^{p} \varsigma_{4} \Delta y_{t-j}+\varepsilon_{t}$

In this case, $\mathrm{H}_{0,1}$ and $\mathrm{H}_{1,1}$ are as presented above, this is because $y_{t}=v_{t}$ are the null and alternative hypotheses. Accordingly, the Wald statistics by equation (10) can be presented as follows:

$W_{0}=T\left(\frac{R S S_{0}^{r}}{R S S_{0}^{u}}-1\right)$

where, $W_{0}$ follows an asymptotic $\chi_{2}^{2}$.

In the cases where the time-series do not have the features of linearity, the nonlinear unit root tests are implemented in order to determine the features of the unit roots. Within this scope, the nonlinear exponential smooth transition autoregressive (ESTAR) models are used commonly in order to model the behaviors of the financial time-series (Gozbas1, 2014: 13). The tests developed by Kapetanios et al. (2003) (hereafter KSS) and Kruse (2011) are used frequently for the nonlinear series within the literature. The nonlinear ESTAR unit root tests suggested KSS (2003) and Kruse (2011) were used in this study. KSS (2003) introduced a test based on the ESTAR model to study the stationarity of the nonlinear time-series. This test is important since it reveals the stationarity globally in case the unit root tests which are based on the linear time-series technique reject the stationarity (Bozkurt and Okumus, 2016: 31).

In the unit root test developed by KSS (2003), the time-series are assumed to follow an autoregressive process in the first stage of the exponential smooth transition and the existence of the unit root which is a null hypothesis is tested against the nonlinear ESTAR stationarity hypothesis which is the alternative one. When the ADF, Perron and Zivot-Andrews tests reject the existence of the unit roots, the mentioned test sometimes brings results on stationarity. This prevents the unnecessary difference and thereby any information loss and also provide an insight for the investors (Ilalan, 2018: 660).

The model used as a base for the KSS unit root test is expressed as follows (Kapetanios et al., 2003: 361-362):

$y_{t}=\beta y_{t-1}+\gamma y_{t-1} \Theta\left(\theta ; y_{t-d}\right)+\varepsilon_{t}$

In the model, $e_{t} \sim \operatorname{iid}\left(0, \sigma^{2}\right)$ and $\beta$ and $\gamma$ indicate the unknown parameters. Additionally, $y_{t}$ represents the zero-mean stochastic process. Following the STAR model literature, the transmission function on the exponential form is presented as follows.

$\Theta\left(\theta ; y_{t-d}\right)=1-\exp \left(-\theta y_{t-d}^{2}\right)$ 
Here, it is presumed that $\theta \geq 0$ and if $d \geq 1$ it is a lag parameter. In the KSS (2003) test, the exponential STAR (ESTAR) model can be presented as follows by using the appropriate parameters. It can be expressed with the equation above (Kapetanios et al., 2003: 361-362):

$\Delta y_{t}=\phi y_{t-1}+\gamma y_{t-1}\left[1-\exp \left(-\theta y_{t-d}^{2}\right)\right]+\varepsilon_{t}$

Here, the raw data can be the data which is acquired from the average or trend-free according to the data production process of the macroeconomic variable discussed. $\varepsilon_{t}$ is an error term that has a normal distribution and is a zero mean and constant variance. The null hypothesis of this test process is $\mathrm{H}_{0}: \theta=0$ and the alternative hypothesis of it is $\mathrm{H}_{1}: \theta>0$. Here, if $\phi=\beta-1$ and $\theta$ is positive in the equation, the mean reversion speed can be determined effectively. In the KSS (2003) test, the ESTAR stationarity process in the alternative hypothesis is studied in consideration of the basic hypothesis which indicates the unit root process.

The nonlinear unit root test of Kruse (2011), which is known as tau test in the literature, is an advanced version of the KSS (2003) test. Whereas the KSS (2003) test assumes $c$ as zero; in the study of Kruse (2011), the emphasis was put on the real-world examples that it is necessary to consider the possibility of non-zero location parameter is imminent (Anoruo and Murthy, 2014: 3). The time-series model which allows the non-null location parameter in the exponential transformation function in the Kruse (2011) test can be presented as below:

$\Delta y_{t}=\phi y_{t-1}\left(1-\exp \left\{-\gamma\left(y_{t-1}-c\right)\right\}\right)+\varepsilon_{t}$

As we employed in the KSS (2003) test, Kruse (2011) applies a first-order Taylor expansion to the transition function, $G\left(y_{t-1} ; \gamma, c\right)=\left(1-\exp \left\{-\gamma\left(y_{t-1}-c\right)^{2}\right\}\right)$, around $\gamma=0$ and proceeds with the regression test and it is possible to get a first order Taylor approximation of equation (115) (Kapetanios et al., 2003: 361-362):

$\Delta y_{t}=\delta_{1} y_{t-1}^{3}+\delta_{2} y_{t-1}^{2}+\sum_{j=1}^{p} \varphi_{j} \Delta y_{t-j}+\varepsilon_{t}$

From the model (15), the null and alternative hypotheses can be redescribed as follows. In equation (15), the null hypothesis of a unit root is $\mathrm{H}_{0}: \beta_{1}=\beta_{2}=0$ and the alternative hypothesis of a globally stationary ESTAR process is $\mathrm{H}_{1}: \beta_{1}<0, \beta_{2} \neq 0$. Note that in $\mathrm{H}_{1}$ the $\beta_{2}$ has two-sidedness due to the fact that the location parameter, $c$, may assume real values (Vasconcelos and Junior, 2016: 120).

In Kruse (2011) the strictly stationary ESTAR process is researched within the alternative hypothesis in consideration of the basic hypothesis, which indicates the unit root process. The $\tau$ statistics suggested by Kruse (2011) is as follows:

$\tau=t_{\beta \square_{2}}^{2}+1(\hat{\beta}<0) t_{\beta_{1}=0}^{2}$

Based on this, Kruse (2011) proposes a $\tau$ test by utilizing the null hypothesis of unit root test it against the $\left(\mathrm{H}_{0}: \delta_{1}=\delta_{2}=0\right)$ globally stationary ESTAR process $\left(\mathrm{H}_{1}: \delta_{1}<0, \delta_{2} \neq 0\right)$. The critical values for this test statistics are presented both KSS et al. (2003) and Kruse (2011). Here, Kruse indicates that tau test carry outs quietly decent in terms of size and power (Anoruo and Murthy, 2014: 3). After the estimation of both models; the statistical value of the parameter in question is compared with the critical table value, and if the null-hypothesis is rejected, the series is decided to be stationarity. 


\section{Data and empirical results}

Most of the empirical studies on testing the weak-form of EMH and RWH focus on the developed stock markets in different parts of the world. To this end, in this study, the return values obtained from the weekly closing values of the indexes which have the highest values and transaction volumes in the exchanges of CEECs. The paper about the RWH of the share prices of the companies listed at CEECs consists of the previous data of them from January 2010 to December 2018, which contains 469 observations, and all the series required for this paper were extracted from investing.com and bloomberg.com databases. All series were transformed into natural logarithms before the analysis to eliminate the scale effect between series. Weekly data is used for 11 countries that are selected among the CEECs depending on the data restrictions. These countries are as follows: Lithuania, Hungary, Romania, Croatia, Slovenia, Poland, Bulgaria, Slovak Republic, Latvia, Estonia, and the Czech Republic. In the study, the linearity of the time-series was primarily tested and according to the results, the nonlinear unit root tests were applied. The test of Harvey et al. (2008) is applied for the linearity, and the DFGLS and Phillip-Perron unit root tests are performed for the linear unit root test while the nonlinear ESTAR unit root tests introduced by KSS (2003) and Kruse (2011) are applied for the nonlinear unit root test.

The indexes, data periods, and the number of observations of the exchanges of the countries were presented in Table 2.

Table 2. Description of stock markets

\begin{tabular}{lccc}
\hline Countries & Stock Markets & Period Covered & Observation \\
\hline Lithuania & Vilnius SE General & $1 / 3 / 2010-12 / 23 / 2018$ & 469 \\
Hungary & Budapest SE (BUX) & $1 / 3 / 2010-12 / 23 / 2018$ & 469 \\
Romania & BET (BETI) & $1 / 3 / 2010-12 / 23 / 2018$ & 469 \\
Croatia & CROBEX (CRBEX) & $1 / 3 / 2010-12 / 23 / 2018$ & 469 \\
Slovenia & Blue-Chip (SBITOP) & $1 / 3 / 2010-12 / 23 / 2018$ & 469 \\
Poland & WIG (WIG) & $1 / 3 / 2010-12 / 23 / 2018$ & 469 \\
Bulgaria & BSE SOFIX (SOFIX) & $1 / 3 / 2010-12 / 23 / 2018$ & 469 \\
Slovak Rep. & SAX (SAX) & $1 / 3 / 2010-12 / 23 / 2018$ & 469 \\
Latvia & Riga General (OMXRGI) & $1 / 3 / 2010-12 / 23 / 2018$ & 469 \\
Estonia & Tallinn SE General & $1 / 3 / 2010-12 / 23 / 2018$ & 469 \\
Czech Rep. & (OMXTGI) & $1 / 3 / 2010-12 / 23 / 2018$ & 469 \\
\hline
\end{tabular}

Source: All data are extracted from the investing.com and bloomberg.com.

Before analyzing the weak-form EMH of the exchanges of the CEECs, descriptive statistics of the used series are investigated. Table 3 of the descriptive statistics gives us the means, the median, the maximum, the minimum, the standard deviation, the skewness and the kurtosis of each series from January 2010 to December 2018. 
Table 3. Descriptive statistics of the stock markets

\begin{tabular}{lcccccccc}
\hline Stock Markets & Mean & Median & Maximum & Minimum & Std. Dev. & Skewness & Kurtosis & Jar-Ber \\
\hline Lithuania & 467.2071 & 454.3700 & 722.0300 & 266.1500 & 118.3957 & 0.524709 & 2.303456 & $31.001^{*}$ \\
Hungary & $24,352.38$ & $22,074.46$ & $40,785.87$ & $14,940.77$ & $7,356.734$ & 0.896421 & 2.379592 & $70.334^{*}$ \\
Romania & $6,446.223$ & $6,472.800$ & $8,920.490$ & $4,216.590$ & $1,246.481$ & 0.114587 & 1.910167 & $24.236^{*}$ \\
Croatia & $1,858.505$ & $1,823.230$ & $2,333.760$ & $1,588.180$ & 159.2231 & 1.132974 & 3.696933 & $109.82^{*}$ \\
Slovenia & 740.6398 & 754.9000 & $1,010.810$ & 501.2700 & 105.7958 & 0.091709 & 2.535467 & $4.8743^{*}$ \\
Poland & $49,868.00$ & $49,077.61$ & $66,897.08$ & $36,549.47$ & $7,125.422$ & 0.305093 & 2.314766 & $16.451^{*}$ \\
Bulgaria & 481.7463 & 454.2500 & 725.4800 & 288.2000 & 117.1011 & 0.317197 & 2.074534 & $24.601^{*}$ \\
Slovak Rep. & 253.3370 & 231.1900 & 359.7900 & 179.4700 & 53.85915 & 0.369644 & 1.529321 & $52.947^{*}$ \\
Latvia & 563.6238 & 439.1400 & $1,071.770$ & 309.0700 & 231.6594 & 1.060111 & 2.598240 & $91.001^{*}$ \\
Estonia & 861.0675 & 826.4100 & $1,316.270$ & 422.0400 & 226.1586 & 0.432605 & 2.111856 & $30.043^{*}$ \\
Czech Rep. & $1,108.825$ & 997.9000 & $1,295.400$ & 811.2600 & 103.8452 & 0.598206 & 2.774426 & $28.966^{*}$ \\
\hline
\end{tabular}

Source: Own computation (E-views).

Notes: ${ }^{*} p<0.01 .{ }^{*}$ denotes that the series are not normally distributed.

As seen in Table 3, the mean values of volatilities of the stock market of CEECs are 467.207, 24,352.38, 6,446.223, 1,858.505 740.6398, 49,868.00, 481.7463, 253.3370, $563.6238,861.0675,1,108.825$, respectively. It can also be observed that the highest value of the stock markets is Poland and the lowest value of them is the Slovak Republic. Also, the standard deviations of volatilities of the stock market of CEECs are found as $118.3957,7,356.734,1,246.481,159.2231,105.7958,7,125.422,117.1011,53.85915$, 231.6594, 226.1586, 103.8452, respectively. It can also be observed that the highest standard deviation of the stock markets is Hungary and the lowest standard deviation of them is Slovak Republic. For a standard normal distribution, skewness should be zero and kurtosis should be at three. It is seen that the stock market series are skewed to the right. It can be observed that the frequency distributions of the above-mentioned series are non-normal distributed based on skewness and kurtosis. The Jarque-Bera statistics also confirm the same.

Figure 1 provides the plots of stock indices over time in changes for the eleven countries. See Appendix 1. Figure 1 reflects the evolution of stock markets of CEECs between the years of January 2010 and August 2018. As seen in Figure 1, the stock price of Lithuania, Hungary, Romania, Poland, Bulgaria, Slovak Republic, Latvia, and Estonia has an increasing trend and has been frequently uptrend by years but the price or return of Croatia, Slovenia, and the Czech Republic is more balanced, and increases and decreases in Croatia, Slovenia, and Czech Republic series are felt most heavily during 2010-2018. In general, it can be observed that the line of all series has monotonically displayed increasing or decreasing trends between 2010 and 2018.

After the descriptive statistics related to the series were determined, it is the turn of the determination of the validity of the weak-form EMH for the exchanges of the CEECs. If the equity market is stationarity; in other words, it does not contain any unit root; the effects of the shocks will be temporary, and this will mean the EMH is valid. On the contrary; if the equity market is not stationarity; in other words, it does contain unit roots; the effects of the shocks will be permanent, and this will mean the EMH is valid in the weak-form. For this purpose, in order to research on the existence of the weak- 
form EMH in the exchanges of the CEECs; among the linear unit root tests, the DFGLS and Phillips-Perron; among the multiple structural break unit root tests, the LeeStrazicich (2003); and among the nonlinear unit root tests, the unit root tests KSS (2003) and Kruse (2011) were applied. The linearity test of Harvey et al. (2008) was used to determine whether the structure of the series is linear. The Eviews 10.0 software was used for the DF-GLS and Phillips-Perron unit root tests which do not consider the breaks; the Gauss 10.0 software was used for the multiple break unit root tests of LeeStrazicich (2003) and the Harvey et al. (2008) test to analyze the linearity of the tests; and $R$ for Windows program was used for the nonlinear unit root tests of KSS (2003) and Kruse (2011).

The weakness of the tests which analyze the stationarity of the series in the literature is the assumption that the series to be analyzed should not contain unit roots; in other words, they should be stationarity. This assumption causes serious problems with the usability of the test. The most important problem is that the linearity test which will be applied to the non-stationarity series can produce misleading results. Especially the factors such as transaction costs for the economic and financial time-series, short selling transactions, price gaps on the purchase and sale of the equities and corporational restrictive practices can cause nonlinearity (McMillan, 2005; Kim et al., 2008). Therefore, before analyzing the series econometrically, analysing the structures of the variables of the economic and financial time-series with the processes and tests suitable for their structures is important for the interpretability of the results. Accordingly, whether the features of the series have linear structures were analyzed primarily in this study. The ESTAR-type test method of Harvey et al. (2008) which tests the linearity and also applied commonly in the literature was used in the study.

Harvey et al. (2008) test is called $W_{\lambda}$ and is distributed as a $\chi_{2}^{2}$. We display the results of applying the $W_{\lambda}$ test in Table 4 . As mentioned earlier, since the stationarity assumption which is one of the strong sides of the Harvey et al. (2008) test was smoothed, another stationarity test was not applied to the series. The results of the stocks market are characterized by Harvey et al. (2008) linearity test.

Table 4. Harvey et al. (2008) linearity test results

\begin{tabular}{lcc}
\hline Stock Markets & $W_{\lambda}$ & Results \\
\hline Lithuania & $10.309^{* * *}$ & Nonlinear \\
Hungary & $13.011^{* * *}$ & Nonlinear \\
Romania & $17.833^{* * *}$ & Nonlinear \\
Croatia & $10.744^{* * *}$ & Nonlinear \\
Slovenia & 0.754 & Linear \\
Poland & $8.270^{* *}$ & Nonlinear \\
Bulgaria & 4.395 & Linear \\
Slovak Republic & 2.909 & Linear \\
Latvia & $29.332^{* * *}$ & Nonlinear \\
Estonia & 3.354 & Linear \\
Czech Republic & 4.240 & Linear \\
\hline Source: Own & &
\end{tabular}

Source: Own computation ( $R$ for Windows).

Notes: The $W_{\lambda}$ statistic follows the $\chi_{2}^{2}$ distribution and the relevant critical values are 9.21 (\%1), $5.99(\% 5)$ and 4.60 (\%10). The estimation and tests were conducted using a program code written in GAUSS that was produced by Harvey et al. (2008). ${ }^{* * *}$ and ${ }^{* *}$ denote the rejection of the null of linearity at the \%1 and 5\% significance level, respectively. 
As a result of the study, the series whose linearity was analyzed were determined to be linear and nonlinear structure. The basic hypothesis of the Harvey linearity test indicated that the series is linear, and the alternative hypothesis of it indicated that the series is nonlinear. In table 4, the hypothesis of linearity is, hence, rejected in 6 cases of 11 CEECs. In Table 4, it can be observed that the basic hypothesis is rejected on the 0.01 and 0.05 significance levels of the series of the selected exchange indexes of Lithuania, Hungary, Romania, Croatia, Poland, and Latvia. In this case; it was concluded that the structures of the exchange series of Slovenia, Bulgaria, Slovak Republic, Estonia, and the Czech Republic are linear in contrast with the structures of the exchange series of Lithuania, Hungary, Romania, Croatia, Poland, and Latvia are nonlinear. After determining the linearity structure of the exchanges, it was the turn of the unit root tests to test the validity of the weak-form of the EMH. The validity of the weak-form of the EMH for the exchanges of the countries with the linearity feature was analyzed with the linear unit root tests of DF-GLS and Phillip-Perron; and two structural breaks unit root test of Lee-Strazicich (2003). Firstly, the DF-GLS and Phillip-Perron unit root tests were applied and the results of them are presented in Table 5.

Table 5. Linear unit root test results

\begin{tabular}{lcc}
\hline Stock & \multicolumn{2}{c}{ DF-GLS unit root test (Intercept and Trend Model) } \\
\cline { 2 - 3 } Markets & Level & 1st difference \\
\hline Slovenia & -0.795175 & $-21.98332^{* * *}$ \\
Bulgaria & -1.334746 & $-11.37111^{* * *}$ \\
Slovak Republic & -1.021779 & $-4.016579^{* * *}$ \\
Estonia & -1.366531 & $-3.864496^{* * *}$ \\
Czech Republic & -2.299399 & $-5.014476^{* * *}$ \\
\hline Stock & Phillips-Perron unit root test (Intercept and Trend Model) \\
Markets & Level & 1 st difference \\
\hline Slovenia & -2.583464 & $-22.00643^{* * *}$ \\
Bulgaria & -2.151323 & $-19.81364^{* * *}$ \\
Slovak Republic & -1.881629 & $-28.94991^{* * *}$ \\
Estonia & -2.652761 & $-21.38647^{* * *}$ \\
Czech Republic & -2.492108 & $-21.74376^{* * *}$ \\
\hline Source: Own
\end{tabular}

Source: Own computation. (E-views).

Notes: This table presents results for unit root tests with an intercept and a trend. ${ }^{* * *}$ denotes the rejection of the null of a unit root at the \%1 significance level at first difference. The unit root test for the DF-GLS were obtained by applying the Schwarz information criteria. For the spectral estimation method Bartlett Kernel was determined and for the Newey-West method Bandwidth options were used. Schwarz information criteria were selected for automatic lag selection. DFGLS test critical values: -3.48 (\%1), -2.89 (\%5), and -2.57 (\%10). Phillips-Perron test critical values: $3.977787(\% 1),-3.419453(\% 5)$, and $-3.132320(\% 10)$.

The unit root tests of DF-GLS and Phillip-Perron were applied to the series firstly to test the efficiency of the series of the exchanges of the CEECs in the weak-form. The results of the double-unit root tests are presented in Table 5. The results of the unit root tests 
presented in Table 5 were reached by extracting the levels and differences respectively. The common result of both tests indicated that when the level values of the series are analyzed with intercepts and trends, the equity exchanges are non-stationarity, in other words, they contain unit roots. It was determined that all series became stationarity in the significance level of $\% 1$ in the DF-GLS unit root tests in their 1st difference. In other words, while the DF-GLS unit root test cannot reject the hypothesis which says the series is non-stationarity in the level in the $1 \%$ significance level; it rejects the null hypothesis which says the series is non-stationarity when the first difference of each series is tested for a unit root. It was determined that all series became stationarity or did not contain any unit roots in the significance level of $1 \%$ in the Phillip-Perron unit root tests in their first difference. In other words, while Phillip-Perron unit root test cannot reject the hypothesis which says the series are non-stationarity in the level in the $1 \%$ significance level; it rejects the null hypothesis which says the series are nonstationarity when the first difference of each series is tested for a unit root. Additionally, it can be observed in Table 5 that the test statistics in the Phillip-Perron test became stronger by getting higher. The results of both DF-GLS and Phillip-Perron unit root tests indicated that all series are integrated into the first difference. Thus, it was concluded that the weak-form of the EMH is valid for the exchanges in the five three countries, namely, Slovenia, Bulgaria, Slovak Republic, Estonia, and the Czech Republic, in other words, those countries have a unit root and follow an RWH. This is suggesting that past values cannot be used to predict the current value. Therefore, it is possible to say that the participants who make investments in those markets cannot provide supernormal returns with those investments.

Although the application of the linear unit root tests is really easy, they cannot obtain the structural breaks and nonlinear trends. As a result, it is suggested that the data is non-stationarity and the series are stabilized with the subtraction method. However, as Brooks (2014) indicated, this operation causes an information-loss on the long-term relations between the variables (Ilalan, 2018: 660). Additionally, it is known through the previous studies that the linear unit root tests have a low level of strength. For this purpose, the new generation unit root tests were applied for the nonlinear trends with breaks for the exchanges of those countries where the weak-form of the EMH is valid.

As the second group of unit root tests, the unit root tests with structural breaks were used in the study. In Table 6, the results of the two structural breaks unit root test of Lee-Strazicich (2003) are presented.

The results of the two structural breaks unit root test of Lee-Strazicich (2003) can be observed in Table 6. The results indicated that the exchange series of the countries are higher than the critical table values in the study of Lee-Strazicich (2003) for the A and $\mathrm{C}$ models, therefore they are non-stationarity at the level in the significance level of $\% 1$, in other words, they do not contain unit roots. It was observed that all series became stationarity after their first difference. Thus, it was concluded that the weak-form of the EMH is valid for the exchanges in the five three countries, namely, Slovenia, Bulgaria, the Slovak Republic, Estonia, and the Czech Republic, in other words, those countries have a unit root and follow an RWH. This is consistent with the weak-form of the EMH suggesting that past movements in stock prices cannot be used to predict their future movements. Accordingly, these results and structural breaks are determined as internal 
and were confirmed by Lee-Strazicich (2003) unit root test. This result implies that the CEECs stock markets are not easily predictable. Consequently, both the traditional and LM structural break unit root tests confirmed the RWH for five countries with a linear structure. It can be implied that investors should not rely heavily on historical prices in an attempt to time the stock markets in these countries.

Table 6. Unit root test with two structural breaks results

\begin{tabular}{|c|c|c|c|c|c|c|c|c|}
\hline \multirow[t]{2}{*}{ Stock Markets } & \multicolumn{8}{|c|}{ Lee and Strazicich (2003) LM Test } \\
\hline & Model A & \multicolumn{3}{|c|}{ Breakpoints $\left(\mathrm{TB}_{1}-\mathrm{TB}_{2}\right)$} & Model C & \multicolumn{3}{|c|}{ Breakpoints $\left(\mathrm{TB}_{1}-\mathrm{TB}_{2}\right)$} \\
\hline Slovenia & -1.371 & \multicolumn{3}{|c|}{$7 / 31 / 2011-3 / 23 / 2014$} & -3.915 & \multicolumn{3}{|c|}{$8 / 26 / 2012-8 / 23 / 2015$} \\
\hline Bulgaria & -1.666 & \multicolumn{3}{|c|}{$12 / 11 / 2011-6 / 08 / 2014$} & -2.329 & \multicolumn{3}{|c|}{$8 / 07 / 2011-2 / 10 / 2013$} \\
\hline Slovak Rep. & -1.600 & \multicolumn{3}{|c|}{$1 / 18 / 2015-2 / 22 / 2015$} & -4.237 & \multicolumn{3}{|c|}{$1 / 06 / 2013-10 / 18 / 2015$} \\
\hline Estonia & -1.957 & \multicolumn{3}{|c|}{$7 / 31 / 2011-2 / 16 / 2014$} & -2.938 & \multicolumn{3}{|c|}{$4 / 17 / 2011-2 / 12 / 2012$} \\
\hline Czech Rep. & -3.467 & \multicolumn{3}{|c|}{$7 / 17 / 2011-8 / 28 / 2011$} & -4.575 & \multicolumn{3}{|c|}{$7 / 17 / 2011-8 / 06 / 2017$} \\
\hline \multicolumn{9}{|c|}{ Critical values for the LM unit root test statistic based on Model C } \\
\hline$\lambda_{2}$ & \multicolumn{2}{|l|}{0.4} & \multicolumn{3}{|c|}{0.6} & \multicolumn{3}{|c|}{0.8} \\
\hline$\% 1$ & $\% 5$ & $\% 10$ & $\% 1$ & $\% 5$ & $\% 10$ & $\% 1$ & $\% 5$ & $\% 10$ \\
\hline-6.16 & -5.59 & -5.27 & -6.41 & -5.74 & -5.32 & -6.33 & -5.71 & -5.33 \\
\hline 0.4 & - & - & -6.45 & -5.67 & -5.31 & -6.42 & -5.65 & -5.32 \\
\hline 0.6 & - & - & - & - & - & -6.32 & -5.73 & -5.32 \\
\hline
\end{tabular}

Source: Own computation (Gauss).

Notes: Lee and Strazicich (2003) indicate the LM-type two break unit root test. $T B_{1}$ and $T B_{2}$ are the break dates. The Model $A$ and $C$ denote the breaks on the intercept and the breaks on the intercept and trend, respectively. Critical values for the LM test based on Model A at 10\%, 5\% and $1 \%$ significant levels are $-3.504,-3.842$ and -4.545 respectively. Critical values for the other coefficients follow the standard normal distribution. $\lambda_{j}$ denotes the location of breaks.

KSS (2003) and Kruse (2011) unit root tests among the nonlinear unit root tests were applied in order to determine whether the EMH is valid in the weak-form for the equity markets of Lithuania, Hungary, Romania, Croatia, Poland, and Latvia which were determined through the test of Harvey et al. (2008). The results of the KSS (2003) and Kruse (2011) test results are presented in Table 7.

Kapetanios et al. (2003) and Kruse (2011) where the null of a linear unit root process is tested against the alternative of a globally stationary nonlinear ESTAR model. The estimated results of the KSS (2003) and Kruse (2011) nonlinear unit root test for Lithuania, Hungary, Romania, Croatia, Poland, and Latvia are presented in Table 7. Table 7 indicates the null hypothesis of unit root could not be rejected for raw, demeaned and detrended series, indicated from the value of $t_{N L}$ which is greater than $t_{N L}$ critical value for all significance level. In line with the results from the KSS test, the Kruse (2011) test also cannot reject the null hypothesis of unit root giving the value of tau test, which is less than their critical value. Both tests suggest that Lithuania, Hungary, Romania, Croatia, Poland, and Latvia have a unit root, and the stock market for these countries is nonstationary. Empirical evidence suggests that the weekly stock prices for the selected stock markets of these countries are efficient in weak-form and exhibit RWH. Accord- 
ingly, it is impossible to say that making predictions through the historical price movements and providing abnormal returns for the investors who think to make investments in the exchanges of those countries. Thus, this result confirms the efficiency of the exchanges of those countries in its weak-form. As a result, these findings evidenced that abnormal returns do not occur in these countries.

Table 7. Results of the ESTAR-type unit root tests

\begin{tabular}{lccc|ccc}
\hline \multirow{2}{*}{ Stock Markets } & \multicolumn{3}{c|}{ KSS $\left(t_{N L}\right)$} & \multicolumn{3}{c}{$\operatorname{tau}(\tau)$} \\
\cline { 2 - 6 } & Raw & Demean & Detrend & Raw & Demean & Detrend \\
\hline Lithuania & 1.944913 & -1.980725 & -2.058675 & 6.114072 & 8.176642 & 5.012147 \\
Hungary & 1.011081 & -0.444442 & -2.608448 & 1.039024 & 5.266097 & 7.042262 \\
Romania & 0.581756 & -2.217067 & -2.878157 & 2.349545 & 4.904826 & 8.710675 \\
Croatia & -0.672917 & -2.016415 & -2.352110 & 6.947133 & 5.466154 & 7.956265 \\
Poland & 0.700364 & -2.189545 & -2.979273 & 3.266712 & 5.815160 & 9.366575 \\
Latvia & & & & & & \\
\hline Critical Values & & & & & & \\
\hline \%1 & -2.82 & -3.48 & -3.93 & 13.15 & 13.75 & 17.10 \\
\%5 & -2.22 & -2.93 & -3.40 & 9.53 & 10.17 & 12.82 \\
\%10 & -1.92 & -2.66 & -3.13 & 7.85 & 8.60 & 11.10 \\
\hline
\end{tabular}

Source: Own computation ( $R$ for Windows).

Notes: $K S S\left(t_{N L}\right)$ : KSS (2003). $\tau$ : Kruse (2011). The critical values for the two statistics are obtained from KSS (2003) and Kruse (2011).The optimum lag length is selected according to Akaike Information Criteria (AIC).

\section{Conclusions and recommendations}

While the companies with the funding needs turn towards exchanges of securities in order to supply long-term funds they need, the investors also turn towards exchanges to provide more returns. Therefore, the exchanges have an active role in the inclusion of the capital of the country. Besides, the steps of the companies contributing the most to the national income of the countries for sustainability have a crucial role in the establishment of the economic stabilization. It is exactly this point where the exchanges in the heart of the finance sector enable new investments by providing pecuniary resources for the companies and enables the companies to receive shares from the profit earned by giving the investor's partnership rights. Those features of the exchanges contribute to the companies, to the investors, and also to the national economy.

Investors apply trading strategies and technical analysis for investment decisions; hence, measuring the efficiency of the stock market is important for both investors and policymakers. Being efficient in the weak-form means for a market that the prices or returns in this market are incidental, in other words, the random walk model is valid for determining the price movements in this market. Accordingly, the weak-form EMH is for testing the RWH. Hence, the issue of EMH is important for analysts, investor's investment decisions, and regulators of the stock market to improve the flow of information. 
The EMH is one of the widely discussed subjects, and therefore, it attracts a lot of attention in the field of modern finance. There is no complete agreement on the efficiency of the equity markets in the literature, and the subject holds its currency in both international and national literature. From this point of view, testing the validity of the weakform of the EMH of the exchanges of the selected countries with the new econometric techniques considered as necessary for the study. The main contribution of this paper is to focus on the issue of nonlinearities in the selected stock market series and the existence of a nonlinear unit root in the series. The objective of this paper is to examine empirically the validity of weak-form market efficiency and RWH in the context of unit root test based on linear and nonlinear techniques of the stock market with the highest value of CEECs. As mentioned before, there are numerous tests in the literature that study whether the economic and financial series are linear or nonlinear. The linearity test of Harvey et al. (2008) has a specific advantage when compared with the others. For this purpose, first of all, the linearity test applied revealed that the selected index returns of Lithuania, Hungary, Romania, Croatia, Poland, and Latvia have nonlinear structure, and indicated that it is necessary to apply nonlinear unit root test to analyze the unit root features of the series in question. After determining the linearity features of those series, the KSS (2003) and Kruse (2011) nonlinear unit root test was applied for the nonlinear series. On the other hand; the selected index returns of Slovenia, Bulgaria, the Slovak Republic, Estonia, and the Czech Republic have a linear structure. The stationarity of the linear series was analyzed with the DF-GLS and Phillip-Perron among the traditional unit root tests, and with the Lee-Strazicich (2003) unit root test with two structural breaks. It was determined with the results of the DF-GLS and Phillip-Perron unit root tests that the selected index returns of Slovenia, Bulgaria, Slovak Republic, Estonia, and Czech Republic contain unit roots, in other words, they are non-stationarity. As a result, the traditional unit root tests supported the weak-form of EMH and RWH for these countries. Also, these results were confirmed supported by Lee-Strazicich (2003) unit root test. According to those results, it was concluded that the markets of the relevant countries are efficient in the weak-form, and the RWH is valid for them. Accordingly, it is impossible to receive successful results from the technical analysis method which is used frequently by the experts and based on the previous price movements in the selected exchange indexes of those countries. Hence one should not be able to make a profit from using something that everybody else knows in the stock markets of the CEECs. It was determined with the results of the nonlinear ESTAR unit root tests applied for the series of Lithuania, Hungary, Romania, Croatia, Poland, and Latvia that the selected index returns of those countries contain unit roots, in other words, they are nonstationary. According to those results, the selected index returns of those countries are observed as effective in the weak-form; therefore, the RWH is valid for those indexes. Thus, the prediction of the future price of all of these markets will be impossible through technical analysis and analyzing the historical prices, investors in these markets cannot provide abnormal returns by carrying out the same analysis. Hence one should not be able to make a profit from using something that everybody else knows in the stock markets of the CEECs. These results are supported by most of the existing studies in the literature. Our findings are consistent with Smith and Ryoo (2003), Hasanov and Omay (2007) Pele and Voineagu (2008), Dragotă and Țilică (2014), Tokić et al. (2018).

This paper examines the weak-form efficiency of the stock markets in CEECs with a specific focus on the weak-form market efficiency. Accordingly, the contribution of this 
paper lies mainly in the application of the selected methodology to CEECs markets for evidence of weak-form market efficiency. Government policymakers and CEECs' stock market participants place a special emphasis on the RWH in the stock market. The existence of the weak-form of EMH in the stock market can allure foreign portfolio investment; promote the domestic savings, and developing the pricing and availability of capital. Therefore, stock markets in CEECs are affected by investor's investment decisions and regulators and such kinds of policies should be implemented. However, it depends on the validity of the semi-strong and strong forms of EMH in the stock markets whether the investors can create profitable investment opportunities through other macroeconomic variables and international macroeconomic factors. Therefore, new researches analyzing whether the semi-strong and strong forms of EMH for the stock markets of the Central and Eastern European Countries are required. Accordingly, it is further suggested that future studies should employ alternative methodologies such as the event study in testing the semi-strong form of efficiency and compare the findings thereof with those in the current study. Further research can be employed with more sophisticated methods of analyzing the weak-form of efficiency. Earning abnormal returns may be investigated by running back testing of technical analysis strategies. The validity of the semi-strong and strong forms of the EMH for those markets can be studied. In our analysis, the weak-form of the EMH was tested on the exchange indexes with the highest value of the CEECs. From this point of view, policy suggestions can be made by comparing the market efficiency between the highest and the lowest exchange indexes by testing the weak-form of the EMH for the exchange indexes with the lowest values of those countries; It can be said that carrying out comparative studies can be useful if the financial data of different countries can be accessed. Furthermore, since the majority of the economic and financial time-series contain unit roots, using the linearity analysis for future studies on linearity will increase the reliability.

Disclosure statement: The author reported no potential conflict of interest.

\section{References}

ABRAHAM, A., FAZAL, J., SULAIMAN, A. (2002). Testing the random walk behavior and efficiency of the Gulf stock markets. The Financial Review, 37, 469-480. DOI: $\underline{10.1111 / 0732-8516.00008}$

ALEXEEV, V., TAPON, F. (2011). Testing weak-form efficiency on the Toronto stock exchange. Journal of Empirical Finance, 18(4), 661-691. DOI: 10.1016/j.jempfin.2011.05.002

AL-LOUGHANI, N., CHAPPELL, D. (1997). On the validity of the weak-form efficient markets hypothesis applied to the London stock exchange. Applied Financial Economics, 7(2), 173-176. DOI: 10.1080/096031097333736

ALOM, K., RAQUIB, M. (2014). Capital market efficiency and portfolio equity inflows in Bangladesh. World Vision Research Journal, 8(1), 202-215. 
ANANZEH, I. E. N. (2014). Testing the weak-form of efficient market hypothesis: Empirical evidence from Jordan. International Business and Management, 9(2), 119123. DOI: $10.3968 / 5524$

ANANZEH, I.E.N. (2016). Weak-form efficiency of the Amman stock exchange: An empirical analysis (2000-2013). International Journal of Business and Management, 11(1), 173-180. DOI: 10.5539/ijbm.v11n1p173

ANLAS, T., TORAMAN, C. (2016). Analysing the efficiency of the Turkish stock market with multiple structural breaks. International Journal of Academic Research in Business and Social Sciences, 6(12), 721-740. DOI: 10.6007/IJARBSS/v6-112/2531

ANORUO, E., MURTHY, V.N.R. (2014). Testing nonlinear inflation convergence for the central African economic and monetary community. International Journal of Economics and Financial Issues, 4(1), 1-7.

ATAKAN, T. (2008). Testing the day-of-the-week effect and January effect anomalies at Istanbul stock exchange with arch-garch models. Istanbul University Journal of the School of Business Administration, 37(2), 98-110.

ATAN, S.D., OZDEMIR, Z.A., ATAN, M. (2009). Weak efficiency on the stock exchange market: An empirical study on ISE. Dokuz Eylul University, Journal of the Faculty of Economics and Administrative Sciences, 24(2), 33-48.

BASHIR, T., ILYAS, M., FURRUKH, A. (2011). Testing the weak-form efficiency of Pakistani stock markets: An empirical study in banking sector. European Journal of Economics, Finance and Administrative Sciences, 31, 160-175.

BORGES, M.R. (2010). Efficient market hypothesis in European stock markets. The European Journal of Finance, 16(7), 711-726. DOI: 10.1080/1351847X.2010.495477

BOZKURT, C., OKUMUS, I. (2016). Are fluctuations in oil consumption permanent or transitory? Evidence from linear and nonlinear unit root test in BRICS-T countries. Cukurova University, Journal of the Faculty of Economics and Administrative Sciences, 20(1), 27-37.

BROOKS, C. (2014). Modelling long-run relationships in finance. In: Introductory Econometrics for Finance (3rd edition). Cambridge: Cambridge University Press.

BUGUK, C., BRORSEN, B.W. (2003). Testing weak-form market efficiency: Evidence from ISE. International Review of Financial Analysis, 12(5): 579-590. DOI: $\underline{10.1016 / S 1057-5219(03) 00065-6}$

CELIK, T.T., TAS, O. (2007). Efficient market hypothesis and emerging markets. $\dot{I} s$ tanbul Teknik Üniversitesi Dergisi, Sosyal Bilimler, 4(2), 11-22.

CHAN, K.C., GUP, B.E., PAN, M.S. (1997). International stock market efficiency and integration: A study of eighteen nations. Journal of Business Finance \& Accounting, 24(6), 803-813. DOI: $10.1111 / 1468-5957.00134$

CHAUDHURI, K., WU, Y. (2003). Random walk versus breaking trend in stock prices: Evidence from emerging markets. Journal of Banking and Finance, 27, 575-592. DOI: $10.1016 / \mathrm{S} 0378-4266(01) 00252-7$. 
CHOUDHRY, T. (1997) Stochastic trends in stock prices: Evidence from Latin American markets. Journal of Macroeconomics, 19(2), 285-304. DOI: 10.1016/S01640704(97)00016-5

CHUVAKHIN, N. (2001). Efficient market hypothesis and behavioral finance is a compromise in sight. Available at http://ncbase.com/papers/EMH-BF.pdf

CONKAR, M.K, CANBAZ, M.F., ARIFOGLU, A. (2018). Causality relationship between the credits of commercial and Islamic banks and economic growth: An econometric analysis. Afyon Kocatepe University Journal of Economics and Administrative Sciences, 20(1), 1-11. DOI: 10.5578/jeas.61920.

ELLIOT, G., ROTHENBERG, T.J., STOCK, J.H. (1996). Efficient test for an autoregressive unit root. Econometrica, 64(4), 813-836. DOI: $10.2307 / 2171846$

EZEPUE, P.O., OMAR, M.T. (2012). Weak-form market efficiency of the Nigerian stock market in the context of financial reforms and global financial crises. Journal of African Business, 13(3), 209-220. DOI: 10.1080/15228916.2012.727750.

DRAGOTA, V., TILICA, E. (2014). Market efficiency of the post-communist east european stock markets. Central European Journal of Operations Research, 22(2), 307337. DOI: $10.1007 / \mathrm{s} 10100-013-0315-6$

FAMA, E. F. (1965). The behavior of stock market prices. The Journal of Business, 38(1), 34-105. DOI: $10.1086 / 294743$

FAMA, E.F. (1970). Efficient capital markets: A review of theory and empirical works. Journal of Finance, 25(2), 383-417. DOI: $10.2307 / 2325486$

FAMA, E.F. (1991). Efficient capital markets: II. The Journal of Finance, V.XLVI(5), 1575-1576. DOI: 10.1111/j.1540-6261.1991.tb04636.X

GEMICI, E., POLAT, M. (2018). Random walk hypothesis in MIST stock markets. Eskisehir Osmangazi University Journal of Economics and Administrative Sciences, 13(1), 129-142.

GILANI, R.T.S., NAWAZ, M., SHAKOOR, M. I., ASAB, M. Z. (2015). Testing the weak-form efficiency of Islamabad stock exchange. Developing Country Studies, 4(11), 79-86.

GOURISHANKAR, S.H., SADATH, A., KAMAIAH, B. (2009). On the random walk characteristics of stock returns in India. Artha Vijnana, 51(1), 85-96.

GOZBASI, O. (2014). Testing weak-form efficiency of the Borsa Istanbul stock market: a nonlinear approach. Verimlilik Dergisi, 0(4), 7-18.

GOZBASI, O., KUÇUKKAPLAN, I. NAZLIOGLU, S. (2014). Re-examining the Turkish stock market efficiency: Evidence from nonlinear unit root tests, Economic Modelling, 38, 381-384. DOI: 10.1016/j.econmod.2014.01.021.

GUMUS, F.B., ZEREN, F. (2014). Analyzing the efficient market hypothesis with the fourier unit root tests: Evidence from G-20 countries. Ekonomski Horizonti, 16(3), 225 237. DOI: $10.5937 /$ ekonhor1403225g 
HAQUE, A., LIU, H-C., NISA, F-U. (2011). Testing the weak-form efficiency of Pakistani stock market (2000-2010). International Journal of Economics and Financial Issues, 1(4), 153-162.

HARRIS, D., MCCABE, B.P., LEYBOURNE, S.J. (2003). Same limit theory for autocovariances whose order depends on sample size. Econometric Theory, 10, 829-864.

HARVEY, D.I., LEYBOURNE, S.J. (2007). Testing for time series linearity. Econometrics Journal, 10(1), 149-165. DOI: 10.1111/j.1368-423X.2007.00203.X

HARVEY, D.I., LEYBOURNE, S.J., XIAO, B. (2008). A powerful test for linearity when the order of integration is unknown. Studies Nonlinear Dynamics and Econometrics, 12(3), 1-24. DOI: $10.2202 / 1558-3708.1582$

HASANOV, M., OMAY, T. (2007). Are the transition stock markets efficient? Evidence from non-linear unit root tests. Central Bank Review, 2(2007), 1-12.

HEPSAG, A., AKCALI, B.Y. (2015). The analysis of weak-form efficiency with asymmetric nonlinear unit root test: The case of G-7 and E-7 countries. BDDK Bankacılık ve Finansal Piyasalar, 9(2), 73-90.

HOOI, L., SMYTH, R. (2007). Are Asian real exchange rates mean reverting? Evidence from univariate and panel LM unit root tests with one and two structural breaks. Applied Economics, 39, 2109-2120. DOI: 10.1080/00036840600722331

HUSSAIN, S., NATH, S.K.D., BHUIYAN, Y.A. (2016). Weak-form efficiency of the Chittagong stock exchange: An empirical analysis (2006-2016). International Journal of Business and Social Research, 6(11), 58-66. DOI: 10.18533/ijbsr.v6i11.1015.

ILALAN, D. (2018). An empirical study of BIST 100 index with nonlinear unit root testing. International Journal of Management Economics and Business, 14(3), 656-665.

IRFAN, M., MARIA, I., MUHAMMAD, A. (2010). Investigating the weak-form efficiency of an emerging market using parametric tests: Evidence from Karachi stock market of Pakistan. Electronic Journal of Applied Statistical Analysis, 3(1), 52-64.

KAPETANIOS, G., SHIN, Y., SNELL, A. (2003). Testing for a unit root in the nonlinear STAR framework. Journal of Econometrics, 112(2), 359-379. DOI: 10.1016/S03044076(02)00202-6

KARAN, M.B. (2004). Yatırım analizi ve portföy yönetimi, Ankara: Gazi Kitabevi.

KAWAKATSU, H., MOREY, M.R. (1999). Financial liberalization and stock market efficiency: An empirical examination of nine emerging market countries. Journal of Multinational Financial Management, 9(3-4), 353-371. DOI: 10.1016/S1042444X(99)00007-9

KHAN, N.U, KHAN, S. (2016). Weak-form of efficient market hypothesis evidence from Pakistan. Business \& Economic Review, 8, 1-18.

KIM, J.H., SHAMSUDDIN, A., LIM, K.P. (2011). Stock return predictability and the adaptive markets hypothesis: Evidence from century-long U.S. data. Journal of Empirical Finance, 18(5), 868-879. DOI: 10.1016/j.jempfin.2011.08.002 
KIM, S-W., MOLLICK, A.V., NAM, K. (2008). Common nonlinearities in longhorizon stock returns: Evidence from the G-7 stock markets, Global Finance Journal, 19(1), 19-31.

KIYILAR, M. (1997). Etkin pazar kuramı ve ektin pazar kuramının IMKB'de irdelenmesi ve test edilmesi. Ankara: Sermaye Piyasası Kurulu, No. 86.

KIYILAR, M. (1998). Etkin pazar kuramının test edilmesi. Yönetim, 9(29), 34-51.

KOFARBAI, H.Z., ZUBAIRU, M. (2016). Efficient market hypothesis in emerging market- a conceptual analysis. European Scientific Journal, 12(25), 260-270. DOI: 10.19044/esj.2016.v12n25p260

KRUSE, R. (2011). A new unit root test against ESTAR based on a class of modified statistics. Statistic Papers, 52(1), 71-85. DOI: 10.1007/s00362-009-0204-1

LEAN, H.H., SMYTH, R. (2007). Do Asian stock markets follow a random walk? Evidence from LM unit root tests with one and two structural breaks. Review of Pacific Basin Financial Markets and Policies, 10, 15-31. DOI: 10.1142/S0219091507000933

LEE, C., LEE, J., LEE, C. (2010). Stock prices and the efficient market hypothesis: Evidence from a panel stationary test with structural breaks. Japan and the World Economy, 22(1), 49-58. DOI: 10.1016/j.japwor.2009.04.002

LEE, J., STRAZICICH, M.C. (2003). Minimum LM unit root test with two structural breaks. The Review of Economics and Statistics, 85(4), 1082-1089. DOI: $\underline{10.1162 / 003465303772815961}$

LEE, C., TSONG, C., LEE, C. (2014). Testing for the efficient market hypothesis in stock prices: International evidence from nonlinear heterogeneous panels. Macroeconomic Dynamics, 18(4), 943-958. DOI: 10.1017/S1365100512000697

LI, W.K., LAM, K. (1995). Modelling asymmetry in stock returns by a threshold autoregressive conditional heteroscedastic model. Journal of the Royal Statistical Society, 44(3), 333-341.

LIU, T. (2010). Stock Market Development and Market Efficiency on China Stock Market. Euro Journals Publishing, Inc.

LO, A.W., MACKINLAY, A.C. (1988). Stock market prices do not follow random walks: Evidence from a simple specification test. The Review of Financial Studies, 1(1), 41-66. DOI: $\underline{10.1093 / \mathrm{rfs} / 1.1 .41}$

MANASSEH, C.O., OZUZU, C.K., OGBUABOR, J.E. (2016). Semi strong form efficiency test of the Nigerian stock market: Evidence from event study analysis of bonus issues. International Journal of Economics and Financial Issues, 6(4), 1474-1490.

MALCIOGLU, G., AYDIN, M. (2016). Analysis of market efficiency at Borsa Istanbul: Harvey linearity test. Journal of Accounting, Finance and Auditing Studies, 2(1), 112123.

MALHOTRA, N., TANDON, K., TANDON, D. (2015). Testing the empirics of weakform of efficient market hypothesis: Evidence from Asia-Pacific markets. IUP Journal of Applied Finance, 21(4), 18-37. 
MCMILLAN, D.G. (2005). Non-linear dynamics in international stock market returns. Review of Financial Economics, 14 (1), 81-91. DOI: 10.1016/j.rfe.2004.09.001

MEHMOOD, M.S., MEHMOOD, A., MUJTABA, B.G. (2012). Stock market prices follow the random walks: Evidence from the efficiency of Karachi stock exchange. European Journal of Economics, Finance and Administrative, 51, 71-80.

MISHRA, P.K. (2011). Weak-form market efficiency: Evidence from emerging and developed world. The Journal of Commerce, 3(2), 26-34.

MOLLAH, A.S. (2007). Testing weak-form market efficiency in emerging market: Evidence from Botswana stock exchange. International Journal of Theoretical and Applied Finance, 10(6), 1077-1094. DOI: 10.1142/S021902490700455X

MUNIR, Q., MANSUR, K. (2009). Is Malaysian stock market efficient? Evidence from threshold unit root tests. Economics Bulletin, 29(2), 1359-1370.

NARAYAN, P.K. (2005) Are the Australian and New Zealand stock prices nonlinear with a unit root?. Applied Economics, 37(18), 2161-2166. DOI: $\underline{10.1080 / 00036840500217887}$

NARAYAN, P.K. (2006). The behaviour of US stock prices: Evidence from a threshold autoregressive model. Mathematics and Computers in Simulation, 71(2), 103-108. DOI: $\underline{\text { 10.1016/j.matcom.2005.11.016 }}$

NARAYAN, P.K. (2008). Do shocks to G7 stock prices have a permanent effect? Evidence from panel unit root tests with structural change. Mathematics and Computers in Simulation, 77(4), 369-373. DOI: 10.1016/j.matcom.2007.03.003

NARAYAN, P., PRASAD, A. (2007). Mean reversion in stock prices: New evidence from panel unit root tests for seventeen European countries. Economics Bulletin, 3, 1-16.

NARAYAN, P.K., SMYTH, R. (2004). Is South Korea's stock market efficient?. Applied Economics Letters, 11(1), 707-710. DOI: 10.1080/1350485042000236566

NARAYAN, P.K., SMYTH, R. (2007). Mean reversion versus random walk in G-7 stock prices evidence from multiple trend break unit root tests. Journal of International Financial Markets, Institutions and Money, 17(2017), 152-166. DOI: 10.1016/j.intfin.2005.10.002

NISAR, S., HANIF, M. (2012). Testing weak-form of efficient market hypothesis: Empirical evidence from South-Asia. World Applied Sciences Journal, 17(4), 414-427.

NOVICKYTE, L., DEGUTIS, A. (2014). The efficient market hypothesis: A critical review of literature and methodology. Ekonomika, 93(2), 7-23. DOI: $\underline{\text { 10.15388/Ekon.2014.2.3549 }}$

NWACHUKWU, J.C., SHITTA, O. (2015). Testing the weak-form efficiency of stock markets: A comparative study of emerging and industrialised economies. International Journal of Emerging Markets, 10(3), 409-426. DOI: 10.1108/IJoEM-07-2013-0115

OZDEMIR, Z.A. (2008). Efficient market hypothesis: Evidence from a small openeconomy. Applied Economics, 40 (5), 633-641. DOI: 10.1080/00036840600722315 
PELE, D.T., VOINEAGU, V. (2008). Testing market efficiency via decomposition of stock return: Application to Romanian capital market. Romanian Journal of Economic Forecasting, 5(3), 63-79.

PERVEZ, M., RASHID, H.U., CHOWDHURY, A.I., RAHAMAN, M. (2018). Predicting the stock market efficiency in weak-form: A study on Dhaka stock exchange. International Journal of Economics and Financial Issues, 8(5), 88-95.

PHILLIPS P.C.B., PERRON, P. (1988). Testing for a unit root in time series regression, Biometrika, 75(2), 335-346. DOI: 10.1093/biomet/75.2.335

PHIRI, A. (2015). Efficient market hypothesis in South Africa: Evidence from linear and nonlinear unit root tests. Managing Global Transitions, 13(4), 369-387.

RAHMAN, M.S., SIMON, H.M., HOSSAIN, M.M. (2016). An empirical analysis of weak-form market efficiency: Evidence from Chittagong stock exchange (CSE) of Bangladesh. Journal of Statistics Applications \& Probability, 5(3), 535-542. DOI: $\underline{10.18576 / \text { jsap/050317 }}$

RYALY, V.R., KUMAR, K.K., URLANKULA, B. (2014). A study on weak-form of market efficiency in selected Asian stock markets. Indian Journal of Finance, 8(11), 3443. DOI: $10.17010 / \mathrm{ijf} / 2014 / \mathrm{v} 8 \mathrm{i} 11 / 71842$

SAID, A., HARPER, A. (2015). The efficiency of the Russian stock market: A revisit of the random walk hypothesis. Academy of Accounting and Finance Studies Journal, 19(1), 42-48.

SAKARYA, S., ZEREN, F., AKKUS, H. T. (2018). Testing the weak form market efficiency in participation indices: An application on Turkey. AKU Journal of Economics and Administrative Sciences, 20(1), 101-113

SAMUELSON, P. (1965). Proof that properly anticipated prices fluctuate randomly. Industrial Management Review, Spring 6, 41-49.

SARIKAMIS, C. (2000). Sermaye pazarlarl. Istanbul: Alfa Yayinlari, Genisletilmis 4. Bask1.

SMITH, G., RYOO, H-J. (2003). Variance ratio tests of the random walk hypothesis for European emerging stock markets. European Journal of Finance, 9(3), 290-300. DOI: $\underline{10.1080 / 1351847021000025777}$

TARI, R. (2014). Ekonometri, Kocaeli: Umuttepe Yayinlari.

TOKIĆ, S., BOLFEK, B., PEŠA, A. R. (2018). Testing efficient market hypothesis in developing eastern european countries. Investment Management and Financial Innovations, 15(2), 281-291. DOI: 10.21511/imfi.15(2).2018.25

WORTHINGTON, A., HIGGS, H. (2004). Random walks and market efficiency in European equity markets. Global Journal of Finance and Economics, 1(1), 59-78.

WORTHINGTON, A., HIGGS, H. (2006). Weak-form market efficiency in Asian emerging and developed equity markets: Comparative tests of random walk behavior. Accounting Research Journal, 19(1), 54-63. 
VASCONCELOS, C.B.F., JUNIOR, L.A.L. (2016). Validity of purchasing power parity for selected Latin American countries: Linear and non-linear unit root tests. EconomiA, 17(1), 114-125. DOI: 10.1016/j.econ.2015.11.001

YANG, G.J-A., LEE, C., LEE, C-H. (2015). Random walk in the MIST. Journal of Asia-Pacific Business, 16(2), 92-104. DOI: 10.1080/10599231.2015.1028303

YARTEY, C., ADJASI, C.K. (2007). Stock market development in Sub-Saharan Africa: Critical issue and challenges. International Monetary Fund Working Paper, No. 07/209.

YUCEL, O. (2016). Financial market efficiency: A study on Borsa Istanbul. International Review of Economics and Management, 4(3), 107-123.

ZAUBIA, K., ALNAHLEH, M. (2010). Financial markets efficiency: Empirical evidence from some Middle East \& North Africa countries (MENA). International Research Journal of Finance and Economics, 49, 180-193.

ZEREN, F., KONUK, F. (2013). Testing the random walk hypothesis for emerging markets: Evidence from linear and non-linear unit root tests. Romanian Economic and Business Review, 8(4), 61-71. 


\section{Appendix 1}

Figure 1. Evolution of stock markets from $01 / 2010$ to 12/2018.
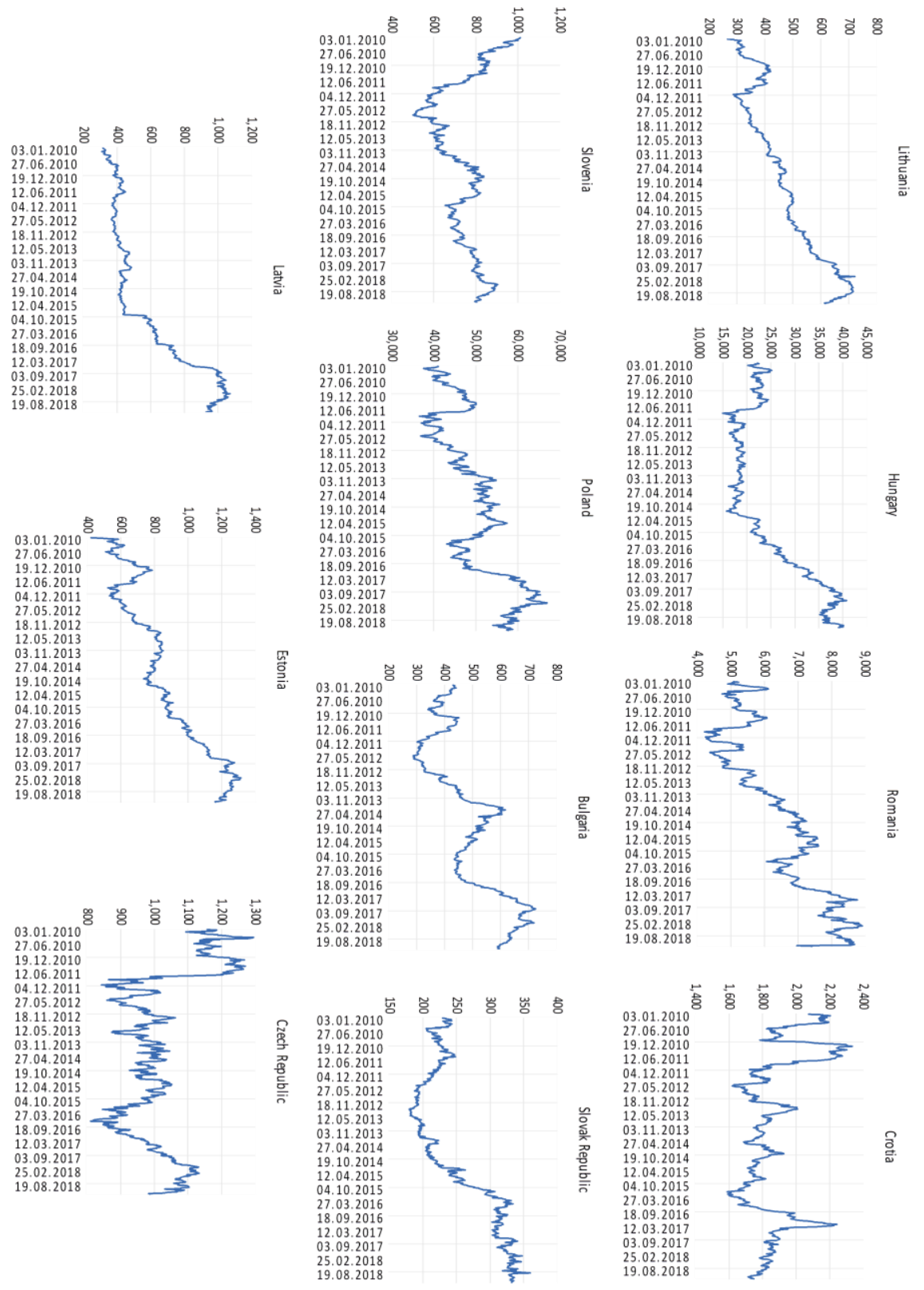

27.06 .2010

9.12.2010

12.06.2011

27.05.2012

03.11 .2013

27.04.2014

12.04 .2015

27.03 .2016

12.03 .2017

25.02 .2018

19.08 .2018 